Pamiętnik Literacki 2015, 3, s. 125-169
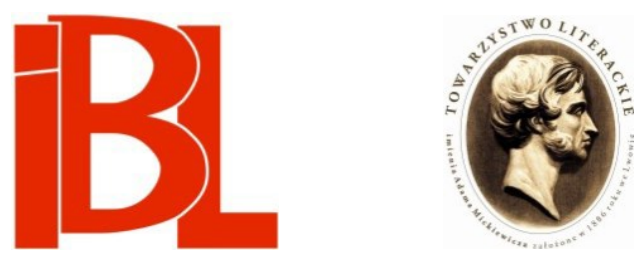

\title{
Polonistyka hejterska. Uwagi do książki
}

„Granice Nałkowskiej”

Hanna Kirchner 


\section{POLONISTYKA HEJTERSKA UWAGI DO KSIĄŻKI „GRANICE NAŁKOWSKIEJ”}

Z okazji przypadającej w 2014 roku 130 rocznicy urodzin i 60 rocznicy śmierci Zofii Nałkowskiej Wydawnictwo Feminoteki opublikowało tom zbiorowy przygotowany przez Agatę Zawiszewską z Uniwersytetu Szczecińskiego'. Tytuł książki, Granice Nałkowskiej, zapowiada intencje rewizyjne. Każda próba nowego odczytania dzieła pisarki, bez banałów rocznicowej ,akademii ku czci”, jest pożądana. Po latach pośmiertnego odrętwienia, szkolnej lektury i niepamięci krytyków Nałkowska wróciła do życia wraz z publikacja jej rewelacyjnych Dzienników z lat 1899-1954 („Czytelnik”, 1975-2001), poprzedzonych rozpoznawczo drukiem ich części - Dzienników czasu wojny (1970, 1972, 1974). Obie edycje z rękopisu, w opracowaniu i $z$ komentarzem piszącej te słowa.

Sukces Dzienników pomnożył wznowienia, „Czytelnik” pokusił się nawet o Dzieła (1976-1990), ale wydał tylko Powieści, Opowiadania, Utwory dramatyczne. Zapowiadane Eseje, Wspomnienia, Szkice z podróży, Dzienniki, Listy, Varia nie ukazały się. Tomy zrealizowane sa, niestety, pełne błędów, z pominięciem słynnego motta Medalionów na czele. Wraz z powolnym zwrotem historyków literatury ku pogardzanej długo epoce Młodej Polski i modernizmu zaczęto odkrywać wczesne powieści Nałkowskiej. Wydawnictwo Literackie sięgnęło po Narcyzę (z moim wstępem, 1967) i Rówieśnice (1978). Rośnie liczba przekładów w Anglii, Francji (Niecierpliwil), w Stanach Zjednoczonych. Jest już pokaźna biblioteka prac o pisarce, młodzi badacze i czytelnicy odnajdują w Nałkowskiej ikonę feminizmu. Przybyła obszerna biografia/monografia Nałkowska albo życie pisane (W.A.B., 2011) mojego autorstwa.

Pozostało przecież jeszcze wiele do odkrycia w tej twórczości. Nowe odczytanie należy się zwłaszcza pisarzom zaniechanym, źle rozumianym przez własną epokę. To paradoks, ale Nałkowska ze swoją wyjątkową pozycją w życiu literackim Dwudziestolecia niejeden raz rozmijała się z gustami i oczekiwaniami krytyków. Nie jest przypadkiem, że sojuszników miała w Witkacym, Schulzu, Gombrowiczu, trzech nowatorach prozy, tak przecież od niej odmiennych. Wysławiano ją i jej nie rozumiano. Nawet świetny debiutant, admirator „doskonałości Nałkowskiej”, Tadeusz Breza, uznał Niecierpliwych za „pamiętną katastrofę literacką, jak mówiono o Ulissesie Joyce'a. Analogia zresztą zastanawiająca.

1 Granice Nałkowskiej. Red. A. Zaw is z ew s ka. Warszawa 2014. Cytaty lokalizuję podając w nawiasie numery stronic. 
Niemal za każdą książka jakiś krytyk żądał, by pisała inaczej i co innego. Gdy po Granicy, obok uznania i Nagrody Państwowej, spadły na nią różne potępienia i nawet obelgi (Kołaczkowski!), rozważała myśl o złamaniu pióra. Zawsze niepewna swego talentu, poczuła mimo to, że - jak zanotowała w Dziennikach - „powinna bronić tego ro d z aj u, tego stanowiska - bo jednak jego wybór jest świadomy i jest wyborem, nie przypadkiem" (9 VIII 1936) ${ }^{2}$.

Jeszcze po wojnie, w jednym z nowych „charakterów” (Gorycze twórczości) odpierała uroszczenia marksistowskich krytyków do pouczania twórcy, ,jak ma pisać, żeby było dobrze, [...] jaki powinien być”. Podważała zuchwale nawet ich tekst liturgiczny: „Byt określa świadomość”, bo wynikający z niego determinizm sprawia, że „stawianie mu w imię tych praw właśnie jakichkolwiek żądań jest bardziej jeszcze daremne niż bezpodstawne". Pisarz Tymoteusz oświadcza więc głosem Nałkowskiej: „Jakkolwiek bym chciał, napiszę tylko tak, jak mogę. Napiszę tylko tak, jaki jestem"3.

Broniła literatury przed naporem „nowych żądań” ideologicznych w programowym artykule przed pierwszym po wojnie zjazdem pisarzy we wrześniu 1945 w Krakowie. Powoływała się na... dzieła Schulza, Gombrowicza, Witkacego - i to na łamach „Kuźnicy”! Kiedyś Paweł Huelle napisał, że tych trzech przypomniano po raz pierwszy w Polsce Ludowej dopiero po 1956 roku. Otóż nie. Ona zrobiła to wcześniej. Sprostowanie istotne przy lekturze omawianej książki.

Zawiera ona 16 tekstów spisanych „piórem niewieścim”, z jednym męskim wyjątkiem. Cechuje ją dziwne niezdecydowanie, jakby niejasna tożsamość i błędnie wytyczony cel. Góruje niewątpliwie bojowy duch feminizmu, aspiracja części tekstów do metod i zasad feministycznej krytyki literackiej, zadomowionej już w polskiej humanistyce. Jest to kierunek, jak wiadomo, wielopostaciowy, wciąż się przeobraża i reinterpretuje, szuka inspiracji w marksizmie i psychoanalizie, sięga też do innych dyscyplin humanistycznych. Do tradycyjnej problematyki badań literackich podchodzi selektywnie, utwór traktuje raczej jako pole rewindykacji ideologicznych. Nie wyczerpuje to pozostałych znaczeń i walorów dzieła. Autorki odwołują się przy tym do koncepcji różnych, często polemicznych względem siebie badaczek zachodnich (oraz Žižka).

Paradoks tej książki zaczyna się od tego, że nie definiuje się jej na wstępie jako genderowej. Czy to założenie, że szyld zbędny, bo zawartość tomu (niejednorodna!) mówi za siebie, czy przekonanie, że teren i metoda interpretacji mają wartość uniwersalną? Decydujące jest jednak to, że niektóre autorki tomu działają na obszarze twórczości i biografii Nałkowskiej jak na terytorium wroga, jak na tekście fallogocentrycznym, gdzie i optyka męska, i język. Tak ukierunkowane reinterpretacje często się $z$ dziełem Nałkowskiej po prostu rozmijają.

Tytuł tomu wskazuje, powtórzmy, na intencje jawnie „lustracyjną” - nie chodzi tu o różne odczytania wielkiej powieści Nałkowskiej. Wstęp redaktorki kreśli - nazbyt ambitnie - cele książki: zmierzenie się z utworami, biografią, recepcją, biblio-

2 Z. N ał kow s ka, Dzienniki. Oprac., wstęp, komentarz H. Kirch n er. T. 4, cz. 2. Warszawa 1988, s. 128.

3 Z. Nałkow s ka, Gorycze twórczości. W: Charaktery dawne i ostatnie. Warszawa 1948, s. 92-93. 
teka prac o autorce Granicy. W ostatnim członie tego wyliczenia nazywa rzeczywiste wytyczne publikacji: ukazać „artystyczne, metodologiczne i ideologiczne "granice" i "ograniczenia" pisania Nałkowskiej i pisania o Nałkowskiej”. Zawiszewska sięga po metaforę mapy, która jest umownym obrazem terytorium, „podporządkowanym doraźny m celom, ale - co istotne - skonstruowanym po dokładnej eks plora cji tere n u” (7; podkreśl. H. K.). Z tej chełpliwej obietnicy książka się nie wywiąuje, a trop feministyczny, jak widać, nie został tu w ogóle ujawniony. Tak samo jak wyznacznik „granic” i „ograniczeń” pisarki. Najwyraźniej to właśnie ten negatywny rewizjonizm ma spajać kilkanaście różnej klasy artykułów i raczej chaotyczny, przypadkowy zestaw tematów.

Anonimowy feminizm wyziera oczywiście, a nawet wybucha, w różnych tekstach tego tomu. Generują go na ogół odniesienia do prac zachodnich autorek i autorów, nierzadko mechanicznie i ahistorycznie przymierzanych do prozy Nałkowskiej, nawet jeśli nie pasują i nic odkrywczego z tego nie wynika. Natomiast bagaż kulturowy epoki, z którego czerpała Nałkowska, słabo jest rozpoznany.

Nazbyt często mamy wrażenie, iż z niejednego szkicu tej książki płynie podskórny lub otwarty przekaz, że pisarka nie wypełnia bieżących postulatów ideologicznych wojującego feminizmu, zwłaszcza sprzymierzonego z marksizmem. Autorki takich prac nie są zapewne świadome tego, że ich sądy mają charakter „czkawki” socrealistycznej, przypomnienia czasów najgorszej opresji w kulturze. Jak w krytyce stalinowskiej, gdy stawiano pisarza pod ścianą, bo „nie dorósł, nie sprostał, nie nadąża” wobec wymagań jedynie słusznej wykładni partyjnej, tak i tutaj robi się to samo w imię płytko lub wręcz aberracyjnie pojętej poprawności politycznej i podobnie rozumianego feminizmu (jak też marksizmu!). W dodatku te konfrontacje ideowe idą $\mathrm{w}$ parze $\mathrm{z}$ mocno powierzchownym obyciem $\mathrm{z}$ twórczościa i biografią pisarki. Stąd nadmierna ilość błędów rzeczowych i nieporozumień. Gdzie redaktorzy, gdzie recenzenci? Z taka „mapą" nie trafi się do celu. W niejednym tekście książki widać wręcz nieumiejętność czytania ze zrozumieniem tekstu literackiego. Przeważa lektura dosłowna, naiwna, często trywialna, a nawet prymitywna. Symbol, aluzja, skrót myślowy, ironia dla niektórych autorek pozostają niedostępną enigmą. Mogą więc one dowolnie wypaczyć sens utworu, posłużyć się insynuacją. Rządzi zasada manipulacji tekstem, by nagiąc go do swej tezy, a także niezgodne $z$ pryncypiami historii literatury utożsamianie poglądów i czynów postaci literackiej ze świadomością autorki. Impet lustracyjny oraz pycha posiadaczek „jedynie słusznej” idei chwilami niepokojąco spokrewniają wywody części tomu z praktykami popkultury. Miałoby się nieraz chęć wyrazić współczucie pewnym autorkom, jak też autorowi, że trafili w takie sąsiedztwo.

Czas przejść od uwag ogólnych do szczegółowych. Dwa pierwsze szkice pokazują antecedencje problematyki feministycznej we wczesnych powieściach Nałkowskiej, a także uporczywość motywu samobójstwa w jej twórczości - tragicznego gestu emancypacji. Praca Anny Godzińskiej Nowa kobieta trafnie wyróżnia składniki lepionego przez młodą pisarkę modelu kobiecości i jej buntu przeciw regułom wyznaczonym „drugiej płci” przez patriarchat. Autorka dostrzega historycznie nieuniknioną bezradność wobec ich nacisku. Sumiennie prezentuje nowsze opracowania tematu. Można było jeszcze zajrzeć do pensjonarskiego dziennika Nałkowskiej - wyjątkowego w naszej literaturze świadectwa adolescencji - i odnaleźć w nim 
komplet słów-kluczy dzisiejszego feminizmu, a także zdać sobie sprawę, że dziewczyna intuicyjnie pojmuje i kwestionuje kulturowe wyznaczniki sytuacji swojej płci. Pozwoliłoby to również zrozumieć, jakie miała wówczas możliwości samorealizacji i czemu małżeństwo - paradoksalnie - stawało się szansą wolności. Przy wszystkich zaletach szkicu Godzińskiej odzywa się w nim wspomniana już skłonność do utożsamiania poglądów i losu postaci utworu z przekonaniami jego autorki. Daje też o sobie znać feministyczny stereotyp: nakładanie pożądanego modelu kobiety dzisiejszej na postaci z innej epoki. Ponadto trzeba sprostować zdania, że Nałkowska „była przeciwniczka pracy kobiet”, a Małgorzata z Rówieśnic została „ukarana za odrzucenie miłości, za potrzebę samorealizacji bez męskiej obecności” (?) (16), bo po prostu kłócą się z treścią utworu.

Postać Janiny z Narcyzy, nauczycielki utrzymującej całą rodzinę z pracy ponad siły, zaniedbanej, wyśmiewanej, rodzi zarzut, że Nałkowska jej „nie lubi” i przedstawia w krzywym zwierciadle, bo to jakoby niemiły jej typ emancypantki: wyzuta z kobiecości, nie w głowie jej miłość i mężczyźni. Jakież nieporozumienie! To już nie sa niedorosłe Kobiety i pogardliwy obraz Smiłowiczowej. W Narcyzie postać Janiny to surowy realizm, świadectwo socjologiczne, twarda konieczność życia, tragizm losu tych kobiet. Przy okazji: Narcyza ni e je st „ostatnią modernistyczną powieścią Nałkowskiej” (16). Jest nią ksiażka Węże i róże (1915).

Zarzut często w tym tomie ponawiany, że dla Nałkowskiej kobieta bez mężczyzny traci kobiecość, że dla niej „o wartości egzystencji świadczy miłość” (18), wydaje się cokolwiek teoretyczny. A co zrobić $z$ „destrukcyjnym” czynnikiem biologicznym, głodem ciała i miłości jako afirmacji osoby? Gabinety psychoterapeutów pełne są ludzi niekochanych. Anatemy dzisiejszych feministek wydaja się nazbyt łatwe i abstrakcyjne. Należałoby raczej dostrzec, jakim wyzwaniem wobec patriarchalnego ideału - Sienkiewiczowskiej Maryni Połanieckiej - był wzorzec kobiecości młodej Nałkowskiej: piękna i mą d ra, wyzwolona, władająca sobą. Ten zuchwały projekt, zderzany z realiami życia w kolejnych książkach, nabierał znamion utopii i ponosił klęskę - samotności, wyobcowania, samobójstwa.

To ostatnie oglądane jest w szkicu Klaudii Ziewiec Samobójstwo w powieściach Zofii Nałkowskiej głównie poprzez losy bohaterów Granicy i Niecierpliwych, co pokazuje, jak „długie trwanie” ma ten wątek w prozie Nałkowskiej. U końca szkicu, w odwróconej chronologii, pojawia się jeszcze postać Marusi z Węży i róż. Dałoby się tę listę rozszerzyć, nie zapominając też o rozmowie Janiny z tytułową bohaterką Narcyzy na temat samobójstwa. Ziewiec rozwija tezy Stefana Chwina z jego pracy Samobójstwo jako doświadczenie wyobraźni (2010) i Barbary Smoleń ze szkicu Płeć i śmierć. Tanatyczna wyobraźnia Zofii Nałkowskiej (2001).

Trudno się nie zgodzić z tezą Ziewiec, że samobójstwa kobiet są u Nałkowskiej desperackim gestem emancypacji, jedyną szansą wyzwolenia $z$ ich sytuacji w świecie androcentrycznym. Pisarka $z$ pewnością ignoruje topos honorowego męskiego samobójstwa. Można jednak zauważyć, że w przypadku Ziembiewicza z Granicy, prócz paru innych powodów jego targnięcia się na życie, jest też moment przedśmiertnej iluminacji moralnej, w świetle której gest samobójczy byłby honorową ekspiacją za własne winy.

Ziewiec podsuwa nam książkę jednej z ważnych myślicielek feministycznych: Rosi Braidotti Etykę stawania-się-niewykrywalnym, i pyta, czy jej tezy dadza się 
zastosować do Nałkowskiej, ale na to nie odpowiada i tych tez nie stosuje. Napomyka także o cechach lektur filozoficznych pisarki, widocznych w watkach samobójczych, jednak ich nie bada, choć Nietzsche byłby tu bardziej na miejscu niż Braidotti.

Jest jeszcze niezbyt fortunne przyzwanie Freuda. Autorka sądzi, że przejawy nerwicy lękowej Marusi z Węży i róż „zdradzają znajomość pism Zygmunta Freuda”, „Jej postać oraz samobójstwo są świadectwem znajomości psychoanalitycznej teorii [...]" (35-36). Jednak to nie $z$ książek, tylko z własnych doznań ciężkiej nerwicy przeżytej przez Nałkowską w Krakowie w 1909/10 roku, zaświadczonej w Dziennikach (łącznie $z$ natrętną myślą o samobójstwie) pochodzą te opisy. Powieść Węże i róże powstawała w latach 1911-1913, pierwszy przekład Freuda ukazał się w Polsce w 1911 roku, a w tym czasie pisarka odnotowywała w dzienniku swoje lektury i Freuda tam nie ma. Zresztą jego popularność u nas objawiła się później.

Tak samo zbyt łatwe jest założenie, że mistrzyni psychologicznego wglądu w człowieka czerpała charaktery Niecierpliwych z książek Freuda i „przeniosła na karty swoich powieści postaci przeżywające konflikty psychiczne opisywane przez ojca psychoanalizy" (37). Co nie znaczy, że podobne nie zdarzały się w życiu, w tym przypadku jej własnym, jej rodziny, jej bliskich. Ponadto wiek XX można by nazwać wiekiem psychologii, tak bogate, tak rozmaite były inspiracje i odkrycia w tej dziedzinie, nie mówiąc już o wkładzie naturalistów oraz Dostojewskiego do wiedzy o człowieku, jak również o swoistym „prefreudyzmie” Młodej Polski („Na początku była Chuć” Przybyszewskiego).

Freud jako j e d y ny inspirator Nałkowskiej powraca nieustannie w tym tomie, zresztą zawsze ogólnikowo albo nietrafnie, o czym dalej. Ustalmy zatem, że po raz pierwszy i ostatni Nałkowska wspomina o lekturze Freuda i swej refleksji nad nia w dzienniku pod datą 12 II 1932. Czytała wtedy najprawdopodobniej Trzy rozprawy z teorii seksualnej (1924). Mogła, rzecz jasna, znać już wcześniejsze przekłady jego prac. Po roku 1918 gdzie indziej notowała swoje lektury, ale na pewno wiemy tylko to, co przytoczyłam.

Jest oczywiste, że freudyzm był „w powietrzu kultury”, ale nadużyciem wydaje się sprowadzanie odkryć psychologicznych pisarki, w tym nawet dość potocznych obserwacji ludzkich zachowań, do jednego źródła. Barbara Zielińska w artykule „Romans Teresy Hennert”: z ukosa, na wprost pisze od razu: „Nałkowska, jak wiemy, żywo interesowała się Freudem" (41). Skąd wiemy?

Zielińska sama „leci Lacanem” i lacanistą Slavojem Žižkiem. Czasem to przydatne, częściej pozostaje zabawą. Np. kiedy twierdzi o uczuciach kochanków, Teresy i Omskiego: „Najważniejsze - sa one wewnętrznie sprzeczne. Jako takie sa absolutnie freudowskie” (42). Ależ to bardzo częste i banalne zjawisko - Hassliebe! Szukałabym raczej w doświadczeniach samej pisarki, bo niejedno z jej wyznań świadczy o takiej ambiwalencji miłosnych uczuć. Wystarczyłby Dostojewski.

Zresztą Zielińska dziwi się wiedzy psychologicznej Nałkowskiej. Analizując postać Teresy Hennert według konceptu miłości dworskiej wziętego z Lacana/Žižka, uzyskuje niejaką zgodność z tekstem powieści. Ocala nawet pewien dowcipny dystans własny do freudowsko-lacanowskiej wykładni. Ale znów w końcowej konkluzji unieważnia poniekąd swoje wywody:

Najciekawsze jednak pozostaje to, co wymyka się świadomości zainteresowanej freudyzmem pi- 
sarki. Rozproszona kompozycja, która buduje świat w ciągym ruchu i - niezależnie od deklaracji autorki - nie dopuszcza wizji osobowości jako czegoś niezmiennego, finezyjne operowanie wiedzą narratora w niewytłumaczalnej zgodności z modelem miłości dworskiej, portretowanie tytułowej postaci w tak nietuzinkowy sposób, że otrzymujemy [...] różne obrazy - wprost i z ukosa. [50]

Trudno dociec sensu tych enigmatycznych zdań: co „wymyka się”, dlaczego „niewytłumaczalnej”? Skąd sprzeczna z treścią książki uwaga, że Nałkowska głosi niezmienność osobowości, podczas gdy słowo „przemiana” rządzi cała powieścią? Czy mamy się domyślać, że Romans wysnuła Nałkowska ze swej (freudowskiej) podświadomości? Cudza sukienka nie pasuje i niewiele wyjaśnia. Model miłości dworskiej może da się też wytłumaczyć pamięcią kulturową pisarki, żarliwej czytelniczki literatury wszystkich epok?

Grupę tekstów oscylujących wokół Granicy otwiera finezyjny szkic jedynego tu mężczyzny, Piotra Krupińskiego, Dom nad szczurami. O „Granicy” Zofii Nałkowskiej. Autor zestawia jedno słowo z opowieści Elżbiety o „ludziach spod podłogi” w kamienicy jej ciotki $z$ ekspresjonistyczną wizją wielkiego miasta w literaturze niemieckiej. Motyw szczura symbolizował tam lęk i odrazę mieszczaństwa w obliczu tłumnej inwazji „rojącego się” plebsu na europejskie metropolie. Ten zwierzęcy symbol obsługiwał różne literackie wizje. Można by dorzucić utwory Hauptmanna i Camusa, a także debiut Adolfa Rudnickiego Szczury (1932).

Tłem dalszych rozważań czyni Krupiński symbolikę domu w tekstach Junga, Bachelarda, Lovecrafta, gdzie oznacza on warstwy, „piętra” świadomości ludzkiej. Rzutuje na te analogie metaforę społecznej struktury wpisanej w budynek na posesji pani Kolichowskiej. Nieodzownym dopełnieniem takiej budowli, realnej i symbolicznej, jest obecność szczura, sąsiada nędzarzy „spod podłogi”. Kumuluje on w sobie wszystkie świadome i podświadome lęki i wstręty człowieka wobec świata „przedludzkiego”, jego zagrażającej inności, a także - dodajmy - odruch eksterminacyjny.

Krupiński skutecznie i twórczo wzmacnia własną subtelną analizę ciemnych stron ludzkiej psychiki, w Elżbiecie współistniejących z empatyczną wrażliwością, odniesieniami do filmu Wstręt Polańskiego oraz do teorii „abiektu” Kristevej, czyli nośnika nieodpartego, najgłębiej ludzkiego odruchu obrzydzenia. Przywołuje inne jeszcze źródło takiego afektu, ściśle splecionego z lękiem: nagłą świadomość zmian zachodzących w ciele starzejącej się kobiety.

Film Polańskiego, późniejszy od Granicy o 30 lat, przypomina Krupińskiemu o tożsamej jak u reżysera umiejętności Nałkowskiej: przedstawienia stopniowego, psychotycznego rozpadu kobiecej osobowości, tutaj - Justyny. Autorka Niecierpliwych bardzo wcześnie, jak wiemy, włączyła zjawisko obłędu do świata przedstawionego swojej prozy.

Krupiński docenia akty transgresji Nałkowskiej i jej bezlitosną uważność wobec rozmaitych tabu archetypalnych czy kulturowych. Używa przy tym określeń: nowatorstwo, arcydzieło, zupełnie wyjątkowych w tym tomie.

Pro domo sua. Autor dyskretnie, w przypisie, nazwał aktem „swoistej cenzury” wobec wymykających się Elżbiecie słów odrazy do „innej rasy”: „szczurzej”, mieszkańców piwnicy, moją jakoby opinię w książce Nałkowska albo życie pisane, że to porównanie jest „kolejnym elementem paradygmatu współczucia” (61, przypis 29). Ale ja stwierdziłam jedynie: „Świadoma koszmaru życia ludzi bytujacych pod pod- 
łogą jej pokoju "jak szczury", nie może znieść faktu, że już przez to, że żyje, godzi

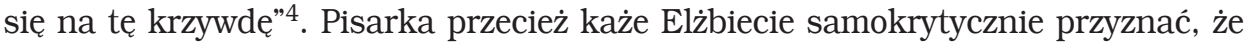
pełna jest, tak jak Zenon, „schematów” myślowych własnego środowiska. Dzięki sile współczucia właśnie przekracza swoje głęboko uwewnętrznione uprzedzenia i odruchy. To trudne przezwyciężenie - lub surowa diagnoza - jest bez wątpienia ważnym osiągnięciem twórczym.

Wdzięczna jestem autorowi szkicu za wycięcie $z$ powieści i niejako powiększenie opisu pajaków, w którym dominuje jednak miłość Nałkowskiej do zwierząt, nawet do szczurów (Choucas!). Z ujmującą sumiennością zidentyfikował on (w przypisie) głównego tancerza baletu pająków jako kosarza pospolitego.

Po błyskotliwej etiudzie Piotra Krupińskiego następuje wielkoformatowe studium Agaty Zawiszewskiej Stużaca jako nagie życie. Zajmuje się postacią Justyny, ale jest ponadto swego rodzaju manifestem ideologicznym, pokazem metody i narzędzi, jakimi autorka preparuje dzieło literackie w celach pozaliterackich.

Rozprawka pomyślana jest ambitnie. Zapożycza od włoskiego filozofa Giorgia Agambena pojęcia nagiego życia i homo sacer, a od Michela Foucaulta termin „biopolityka”, odwołuje się do wielu prac obcych i polskich, traktujących o rozmaitych formach współczesnego niewolnictwa. Jego przykładami są choćby obozy koncentracyjne, a także różne przypadki zawieszenia wszelkich praw obywatelskich - jak w stanie wyjątkowym - ale w toku pokojowej egzystencji, np. w więzieniu, w szpitalu i wobec niektórych grup społecznych.

Dotyczy to w znacznej mierze kobiet, Zawiszewska włącza tu zatem opis brutalnych represji władzy wobec brytyjskich sufrażystek, a szczególnie odrębnej i licznej grupy niewolników - służących. Streszczając tezy Agambena, autorka pisze:

Nagie życie stanowi tu rewers suwerennej władzy [chyba: władzy suwerena?], jej efekt i punkt odniesienia, ponieważ włączone jest do tego, co polityczne, tylko w formie wykluczenia i wystawienia na przemoc nieuznawaną za przestępstwo. [71]

W nowożytnych państwach to wykluczenie i bezprawna przemoc spotykaja „ludzi bez obywatelstwa, uchodźców, imigrantów, osadzonych w zakładach penitencjarnych, pacjentów podłączonych do aparatury podtrzymującej życie itd.” (71).

Po zreferowaniu tez Agambena i brytyjskich historyczek emancypacji (za praca Ewy Płonowskiej-Ziarek Strajkujace nagie życie. Uwagi o biopolityce rasy i gender) autorka bada przedwojenne konstytucje Rzeczypospolitej z lat 1921 i 1935 pod kątem praw obywatelskich kobiet, jak również projekty zmian prawnych, nad którymi pracowała Komisja Kodyfikacyjna, poddając je pod publiczna dyskusję. Wywołało to zasadnicze spory wokół prawa małżeńskiego, ochrony macierzyństwa i planowania rodziny. Zmian nie wprowadzono.

Zawiszewska cytuje następnie autorów badających sytuację służących w II RP, co składa się istotnie na obraz populacji niewolniczej, niechronionej prawem. Zawarte w kodeksach przepisy o ochronie macierzyństwa dotyczyły tylko mężatek, a ponadto kobiet pracujących w przemyśle, ale już nie służących w domach prywatnych i robotnic w małych zakładach i warsztatach. To głównie one rodziły nieślubne dzieci. Szczegółowy opis nienormowanej pracy służących, wymagań chlebodaw- 
ców oraz zaleceń moralnych dla niepiśmiennych na ogół dziewcząt ze wsi, samotnych w mieście i bezdomnych, gdy zostały zwolnione przez „państwa”, stanowi przejmujący wstęp i tło do analizy głównego wątku Granicy. Wartość poznawcza tej części rozprawy, można powiedzieć: socjologiczno-prawnej, jest bezsporna. Watpliwości i protesty rodzą się dalej, gdy Zawiszewska przystępuje do analizy powieści.

Pewien opór budzi zreszta już początek jej rozważań, mówiący, że „przedmiotem obserwacji Nałkowskiej w Granicy stała się - obok innych zjawisk i procesów społecznych i politycznych - nowoczesna biopolityka, czyli zarządzanie populacja” (70). Język ten niebezpiecznie zbliża utwór artystyczny do piśmiennictwa innej natury i przeznaczenia.

W podrozdziale Nagie życie autorka cytuje krytyków, którzy czyn Justyny traktują jako zemstę klasową - od Jana Nepomucena Millera po Włodzimierza Wójcika. Ten ostatni jednocześnie dyskredytuje Justynę: infantylna, prymitywna, nieodpowiedzialna, kapryśna, prostacka, wulgarna, ma uproszczone wyobrażenia o świecie. „Jest taka, jaka ją uczyniły społeczne warunki jej klasy społecznej”, konkluduje niezdarnie Wójcik ${ }^{5}$.

Zawiszewska dopomina się o uznanie osobistych motywów zemsty Justyny za równie doniosłe jak „,klasowe”. Służba bowiem nie przynależy do proletariatu, „i jako jednostki, i jako wspólnota - nie jest bytem politycznym, nie ma więc tożsamości" (84). Służba to w większości kobiety, dotyka je przemoc nie tylko klasowa, ale i genderowa, są wykorzystywane zarówno ekonomicznie, jak i seksualnie. Służąca jest niewolnica prywatna, wyrzuca się ją, gdy choruje, gdy jest w ciąży - bo już „niezdatna”.

Dopóki autorka tych rozważań referuje swoje lektury i stara się zilustrować je tekstem Granicy, śledzimy jej wysiłki z zainteresowaniem. Dalej jednak w ferworze rewolucyjnym zaczyna bronić postaci Justyny przed jej kreatorką i wykrywa coraz to nowe ideologiczne grzechy Nałkowskiej. Paliwem zapału badaczki jest wyraźnie feminizm infekowany marksizmem. Porzuca ona zadeklarowane wcześniej inspiracje i roztacza cały repertuar nieboszczyka socrealizmu. Historia nie jest nauczycielką życia, bo ma przeciw sobie amnezję kolejnych pokolen. Niekiedy gorliwie galwanizują one trupa prześladowcy ich ojców i witają w nim proroka.

Badaczka stosuje więc narzędzia agresywnej insynuacji ideologicznej i znaną z początku lat pięćdziesiątych zasadę stawiania twórcy pod pręgierzem za to, że pisze, jak jest, a nie - jak być powinno, że nie sprostał zadaniom pisarza-propagandysty. Nieuchronnie egzegetka ideologiczna rozmija się $z$ faktyczną wymową tekstu. Nie rozumiemy tego, bo przed chwila wydobyła $z$ powieści niebywałą liczbę szczegółów ilustrujących krzywdę "nagiego życia”, sankcjonowaną nie tylko ustrojem, ale też obyczajem, tak powszechnym i odwiecznym, że wydaje się „naturalny”. To wyliczenie jest wręcz mimowolnym hołdem dla przenikliwości i geniuszu obserwacyjnego Nałkowskiej.

Zawiszewska jednak nie daje się nabrać. Demaskuje natomiast postać Elżbiety, w której żywiołowe odruchy buntu i empatii współżyją z podświadomymi uprzedzeniami (co analizował już Krupiński), jako emanację świadomości samej pisarki.

5 W. Wój cik, wstęp w: Z. N ałkow s ka, Granica. Oprac. ... Wrocław 1971, s. LXXV. BN I 204. 
Niechęć, wstręt i strach wobec nagiego życia stanowią treść podświadomości narratora, przekazującego własne mentalne zapętlenia swoim bohaterom, szczególnie Elżbiecie, Zenonowi i pani Cecylii, również na temat „niezorganizowanego erotyzmu” [...]. [91; podkreśl. H. K.]

Uzasadnieniem tej interpretacji ma być zdanie z książki Ewy Frąckowiak-Wiegandtowej Sztuka powieściopisarska Nałkowskiej (lata 1935-1954) (1975), mówiące, że postać narratora to „źle dopasowana maska, spoza której przeziera autor [...]" (cyt. 91, przypis 59). Tylko że przywołanej badaczce chodzi o zupełnie inny przejaw obecności autora w Granicy, jak również w nowoczesnej powieści europejskiej. Pisałam i ja o roli autora w tym utworze, a także o powierzaniu Elżbiecie pewnych autorskich refleksji oraz postaw, ale nie takich właśnie, jakie Zawiszewska bez namysłu imputuje. Elżbieta jest przede wszystkim postacią świata przedstawionego, prowincjonalnej Polski międzywojennej, mówi przez nią „złe sumienie” i zdradza się bagaż kulturowy mieszczańskiej inteligentki.

Czemu tyradę Cecylii Kolichowskiej przeciw „tamtym”, kradnącym mężów prawowitym małżonkom, badaczka odnosi wprost do służących jako uwodzicielek (bywało przecież odwrotnie)? Pani Cecylia ma na myśli „dziedziny niezorganizowanego erotyzmu”, „pojęcie kolektywne”. Nałkowska dotyka tu zjawiska uniwersalnego, doświadczenia i zgryzoty wszystkich kobiet. Zawiszewska sięga po wyjaśnienie trywialne, jak z harlekina czy serialu: Nałkowską pierwszy mąż zdradził ze służąca, stąd jej wstydliwa i „określona klasowo” niechęć do służących, która „została przekierowana na "tamte", zasługujące na klasowo uzasadnione potępienie partnerki przedstawicieli "władzy" [...]" (91).

O kim więc mowa? Czy Zawiszewska zna wspomnienie Zahrtowej, cytującej relację pisarki o „początku Justyny” ${ }^{\text {? }}$

„Klasowość” Nałkowskiej ma tu własności obrotowe: niechęć do kobiet z proletariatu, a zarazem potępienie rządzących - jednak. To pierwsze jest jawnym pomówieniem, ignoruje nie tylko treść i wymowę Granicy, ale też całej twórczości Nałkowskiej! Zawiszewska posuwa się dalej:

Nałkowska tak usilnie stara się odwrócić uwagę od własnego resentymentu wobec kobiet $z$ proletariatu, że nieopatrznie [?] ujawnia resentyment wobec kobiet $\mathrm{z}$ warstw uprzywilejowanych, szczególnie wobec arystokracji. [92]

Chodzi tu o hrabinę Tczewską, którą przelotnie spotkał w redakcji Ziembiewicz i którą oglądamy jego niechętnym wzrokiem. Autorka szkicu sięga po argumenty kuriozalne. Dowodzi, że arystokraci artykułem konstytucji marcowej pozbawieni zostali przywilejów rodowych, stanowych, herbów i tytułów, więc ich status jest tożsamy z „nagim życiem”, status hrabiny zaś z „tamtymi”, bo „żywiołowo” urodziła aż dziewięcioro dzieci. W dodatku obie klasy pisarka traktuje metafora zwierzęco-biologiczną: „ludzie spod podłogi” roją się jak szczury, hrabina ma ciężki odwłok, jak niektóre owady, a do tego tak jak tamci uprawia „reprodukcje [...] poza granicami prawa ustanowionymi przez suwerenną władzę" (92). Czy w konstytucji ograniczono też arystokracji liczbę dzieci?

Nałkowska czuje zatem niechęć do obu stanów z przyczyn, oczywiście, klaso- 
wych jako mieszczańska inteligentka. Przy każdym aspekcie powieściowej rzeczywistości Zawiszewska powiela ten sam, przyswojony na wstępie, zasób pojęć socjopolitycznych. Oskarżycielski impet jej retoryki sprawia wrażenie, iż opisane nieprawości autorka Granicy firmuje i popiera. Nawet kiedy Zawiszewska półgębkiem przyznaje, że Nałkowska zobrazowała przecież w znacznej mierze przewiny systemu i jego „biopolityki”, która „wymaga [...] prawnie skonstruowanego nagiego życia zdeterminowanego genderowo [styl!] oraz przestrzeni permanentnego stanu wyjątkowego [...]” (95) itd., to jednak nie ustaje w poszukiwaniu jej „ograniczeń”. Mimo że pisarka słusznie uczyniła „romans” centralną sprawą powieści, świadoma (jednak!) „politycznego wymiaru tego, co w kulturze postrzega się jako najbardziej prywatne i intymne" (96). Zawiszewska podpiera się tu opinią Ingi Iwasiów o politycznym wymiarze Granicy, której autorka „Z powieści o władzy czyni jednak [...] powieść o relacjach międzyludzkich [...]" (cyt. 96). Dodajmy nawiasem, że sprawowanie władzy to też relacje międzyludzkie.

Wróćmy do win Nałkowskiej, i to ciężkich. Zawiszewska przypisuje autorce głosy otoczenia o Justynie:

Nazwanie „histeria”, „obłąkaniem”, „dziwnością” czy „zmanierowaniem” psychosomatycznych reakcji Justyny na absolutne wywłaszczenie $\mathrm{z}$ tożsamości, a także sam finał Granicy uniemożliwia odczytanie ich jako komunikatu sformułowanego w języku nagiego życia uwikłanego genderowo ani też nie pozwala dostrzec potencjału emancypacyjnego, jaki się w nich kryje. [97]

W tej topornej stylistyce badaczka snuje dalej wykaz „ograniczeń” pisarki:

Nałkowska nie dała Justynie szansy przekształcenia jej gniewu w narzędzie politycznej zmiany nie tylko $\mathrm{z}$ powodu nieatrakcyjności komunizmu jako alternatywnego porządku politycznego, lecz również z powodu własnych ograniczeń mentalnych i planów artystycznych. [...] nie pozwoliła Justynie odegrać roli dziejowej przez to, że uczyniła z niej osobę niestabilną emocjonalnie. [100; podkreśl. H. K.]

Tak podsumowana autorka Granicy ma jeszcze u Zawiszewskiej nikłą szansę, bo „pozwala jej [tj. Justynie] postępować pod wpływem gniewu i pomścić własną krzywdę [...]" (101), czyli wykroczyć poza literacką tradycję kobiecego wybaczania mimo skarg. Ale jest wina następna. „Skandalem” ma być według pisarki nie wykorzystanie Justyny przez Ziembiewicza, tylko przedostanie się sprawy do wiadomości publicznej (to jednak znów niezgodne $z$ tekstem powieści!), co świadczy, oczywiście, o zachowawczej mentalności Nałkowskiej.

Finał tego „sądu nad Granica” zaskakuje: Zawiszewska nagle oświecona przez francuskiego filozofa Jacques'a Rancière’a, że

działanie polityczne literatury nie polega na dyskursywnym rozwiązywaniu problemów społecznych [...], lecz na ich zobrazowaniu i oświetleniu z innej perspektywy niż dotąd, by uczynić je na nowo „widocznymi”. [102]

- trzeźwieje na koniec z rewolucyjnego zapału feministycznego (który w takiej postaci chyba nie przysłuży się słusznej skądinąd sprawie). Pieczętuje nawet Francuza Gombrowiczem, czyli znana jego wypowiedzią o Granicy. Tyle że zdąża do tego tropem rzekomego grzechu pierworodnego Nałkowskiej - egocentryzmu. Po drodze przydarza się jej pomyłka: w zdaniu „Międzywojenni recenzenci powieści - pisząc, 
że forma jest kategoria etyczną, ponieważ wyraża moralność pisarza - piętnowali wykształcony na modernistycznym etapie jej twórczości egocentryzm [...]" (103). Wszyscy krytycy orzekali to samo? Tymczasem zdanie o związku formy z moralnościa jest tezą samej Nałkowskiej z jej programowego artykułu Pisana rzeczywistość (1926), którą nie raz przywoływała.

A cóż ma forma do egocentryzmu? Wzięte $z$ książki Ewy Wiegandtowej dowody na ten egocentryzm mówią o czymś innym, a cytat z Anny Zahorskiej już się zupełnie $z$ tą kwestią rozmija. Zarzut egocentryzmu czy też narcyzmu, powtarzany bezrefleksyjnie, powinien w badaczce feministycznej obudzić czujność: kto i dlaczego to mówi? Przystawiany do międzywojennej twórczości pisarki jest absurdalny, do wcześniejszej - mylony z indywidualizmem epoki i naglacym imperatywem „rozeznania się w jestestwie swoim” uświadomionej kobiecości. Wystarczyłoby mieć w pamięci sentencje zeszłowiecznych działaczek ruchu kobiecego: Kazimiery Bujwidowej „kobieta jest sama dla siebie celem” oraz Marii Turzymy „Rozwój jej jako jednostki ludzkiej jest najpierwszym jej prawem i obowiązkiem".

Po tym przewodzie lustracyjnym (czy raczej partyjnej nagonce, zważywszy marksistowskie wzory) dostajemy przyczynek, którego pożyteczność ograniczaja różne mankamenty. Adrianna Seniów w omówieniu Zofii Nałkowskiej praca nad językowo-stylistycznym kształtem "Granicy” zestawia rozdziały powieści publikowane w „Tygodniku Ilustrowanym” $\mathrm{z}$ wydaniem książkowym ostatnim za życia pisarki, zamiast z wydaniem pierwszym z 1935 roku. Nie wiemy zatem, z której publikacji pochodza poprawki. Nałkowska wprowadzała drobne korekty językowe do każdej niemal nowej edycji swoich powieści, a po 1945 roku, zwłaszcza po 1949, brali się do poprawek redaktorzy i cenzorzy i nie zawsze udawało się je odrzucać.

Kategoria błędów gramatycznych również budzi wątpliwości, bo autorka analizy nie bierze pod uwagę zmieniających się zasad poprawności językowej. Zwrot „przyrządzić białej kawy” był kiedyś w powszechnym użyciu, gdy późniejsza niepoprawna tendencja do zastapienia dopełniacza biernikiem sprawia, że tamte formy wydają się błędne. Wrażenie psują także błędy korektorskie w tekście Seniów: „sensu lagro” zamiast „largo”, Posztarska zamiast Posztraska, bałagan w kolejności przytoczeń, a nawet brak wersji z czasopisma (114). Nie wzięto wreszcie pod uwagę błędów drukarskich ówczesnej prasy.

Artykuł Joanny Krajewskiej „Jestem inna niż oni...” „Granica” i Zofii Nałkowskiej poszukiwanie siebie $w$ autokomentarzach $i$ recepcji dotyka istotnego $\mathrm{z}$ pewnościa punktu w świadomości twórczej i w osobowości pisarki, czyli potrzeby ciągłego definiowania własnej tożsamości i wprowadzania do niej korekt. Był w tym wytrwały upór, stanie przy swoim i zarazem niepewność, podszyta dążeniem do perfekcjonizmu, tak bardzo typowym dla kobiet.

Krajewska zaczyna od stwierdzenia, że Nałkowska „wyłuskiwała własny światopogląd z tego, co czerpała od innych”, poszukiwała „tożsamości kobiety pisarki oraz własnego miejsca na literackiej scenie [...] zawsze w odniesieniu do relacji z innymi: najpierw z Karolem Irzykowskim, następnie z Krležą czy "przedmieścianami"” (126). Jest to niefrasobliwa insynuacja, redukująca osobowość pisarki do żeńskiego golema lepionego przez innych. I dlaczego akurat przez tych? Każdy twórca definiuje siebie w odniesieniu do mistrzów dawnych i współczesnych, żyjących i czytanych, to oczywiste, ale to „zawsze”, „w odniesieniu do relacji” i „następ- 
nie” budzi szereg wątpliwości. Podobnie jak zdanie początkowe: „Próbując znaleźć swój artystyczny idiom, intensywnie pracowała nad Granica" (126), sugerujące, że przez 30 lat twórczości Nałkowska nie posiadła jeszcze swego „idiomu”. Szukała przecież czego innego i nie o środki artystyczne tu szło, tylko o sprostanie próbie syntezy czasu, trafne rozpoznanie jego konfliktów i wybór wartości.

Przywołanie „relacji” młodej Nałkowskiej z Irzykowskim, recenzentem czterech pierwszych jej książek w 1909 roku, a w 1911 także Narcyzy, ma tę wartość, że przypomina, iż krytyk dostrzegł wyzwoleńczą stronę pisarstwa kobiet, jako świadectwa ich upodmiotowienia i prób autodefinicji: „odsłoniły swoja płeć”. Autorka zatrzymuje się nad jego uwagą, że mężczyzna ciekaw jest, „co dzieje się w tym światku, bo jest w tym i socjalnie, i erotycznie zainteresowany" (cyt. 127), ponieważ prowadzi ją to do „erotycznej dygresji” (jak to nazwała Nałkowska) znajomości pisarki i krytyka. Pamiętajmy, że Irzykowski, zanim spotkał Nałkowską osobiście, uznał ją za najciekawsza przedstawicielkę kobiecego nurtu w literaturze.

Trudno się zgodzić ze zdaniem Krajewskiej, że w Narcyzie „wyczytał sprawozdania $z$ ich miłosnej szarpaniny" (129), bo niczego takiego nie mógł w tej powieści znaleźć. Poza tym „szarpanina” nie była „ich”, tylko jego (wystarczy zajrzeć do Dzienników) i nigdy nie wybaczył on Nałkowskiej, że nie odwzajemniła jego uczuć. Różne złośliwości i aluzje Irzykowskiego w recenzji Narcyzy z tego zawodu się brały, podobnie jak w innych jego artykułach obsesyjne ataki na autobiografizm i "niedyskrecję" pisarstwa kobiet w ogólności. Do tego jeszcze wrócę, tak jak wraca w tej książce postać Irzykowskiego.

Krajewska sugeruje, że negatywny przeważnie odbiór literatury kobiet mógł zadecydować „o zmianie paradygmatu literatury uprawianej przez Nałkowską” (130). Nie pamięta o tym, że wczesne powieści pisarki cieszyły się znacznym rozgłosem, jak też uznaniem wybitnych krytyków, aprobujących ich kobiecą optykę, mimo Weiningera i mizoginizmu Młodej Polski. „Wsobność” tamtych książek jest względna, jeśli wejrzeć w tło historyczne i społeczne Księcia, Rówieśnic, opowiadań, zwłaszcza Rzeczywistości, oraz Narcyzy, a także pamiętać, jak odmienna od poprzednich jest bohaterka Węży i róż, Marusia. W tej właśnie powieści z lat 1911-1913 sa już zapowiedzi tego, co w artykule $O$ sobie z 1929 roku nazwała Nałkowska, definiując przemianę swej prozy: „rzeczy małe i mali ludzie”.

Czy przypadkiem Nałkowska nie zaznała naprawdę agresji krytyków wtedy właśnie, gdy przyjęła perspektywe „uniwersalna”, zawarowana dotychczas dla mężczyzn? Przemilczano przecież Hrabiego Emila, książkę o wojnie i męskim protagoniście, a potem niosły się skargi, że ignoruje męskie sprawy, jakby mało ich było w Romansie Teresy Hennert, Domu nad łakami, Niedobrej miłości, obu sztukach i Ścianach świata. Rysowanie linii rozwojowej twórczości Nałkowskiej wzdłuż meandrów recepcji wydaje się chybione.

Nieoczekiwanie między Irzykowskiego a Frydego wprowadza Krajewska system pojęć wyłożonych w książce dwóch angielskich badaczek literatury kobiecej, Sandry M. Gilbert i Susan Gubar No Man's Land. The Place of the Woman Writer in the Twentieth Century (1988). Odwołują się one do pomysłu Freuda, czyli do kompleksu kastracji i zazdrości o penisa, który spada na dorastającą dziewczynkę i domaga się wyboru między matką, ojcem (najbardziej pożądanym) i tendencją homoseksualną (jeśli to kwestia wyboru...). Przenoszą ten koncept na historię literatury, 
uważając, że kobiety autorki stają przed wyborem tradycji matry- lub patrylinearnej. Tu znów rodził się kolejny „kompleks przynależności”. Poniecham przytaczania dalszych, szczegółowo referowanych propozycji Gilbert i Gubar, bo nie maja one wielkiej styczności z tematem szkicu.

Miała to być podbudowa teoretyczna wyobrażeń Krajewskiej, jak to Nałkowska miota się całe życie w poszukiwaniu identyfikacji literackiej. Tymczasem jej „matry” to była zarówno Poganka Żmichowskiej, Malwina, czyli domyślność serca Wirtemberskiej, jak George Sand, Colette, a „patry” moraliści i moderniści francuscy, Proust, a nade wszystko Dostojewski, i obie linie zarówno, mówiąc w największym skrócie.

W końcu sama Krajewska porzuca obie Brytyjki i proponuje zamiennik:

Jeśli pod trudność wyboru między tradycją matry- a patrylinearną podstawić eksplorowanie kobiecości versus uniwersalnego punktu widzenia, otrzymamy też dobry punkt wyjścia do analizy twórczości Nałkowskiej. [133]

Nie można było tak od razu? Tylko to albo-albo na autorce Narcyzy się nie sprawdza. Krajewska odgrzała tu teorie już przez feministyczną krytykę wyminięte.

Dalej potrąca - cytatami z Podrazy-Kwiatkowskiej i Górnickiej-Boratyńskiej kwestię definicji kobiecości u Nałkowskiej jako emanacji natury. Dodajmy, że to jedna $z$ idei teoretyczek gender. Nie jest to przecież jedyny składnik jej modelu kobiety, ale nad tym autorka się nie zastanawia, przypomina za to znów wyznanie pisarki o przemianie jej twórczości. Gdyby dobrze się wczytała we wczesne książki Nałkowskiej, byłoby dla niej jasne, że i tam poświęcała ona uwage „skromnym i cierpiącym ludziom" (135). Nie na tym polegał przełom w tej prozie.

Zaraz po tym Krajewska przytacza obszerne fragmenty artykułu Ludwika Frydego o Granicy, będącego w istocie egzegezą całego dorobku pisarki, opartą głównie na wyliczeniu jej braków i słabości, z nieodzownym narcyzmem, egotyzmem, solipsyzmem „pustych” (?) bohaterek i relatywizmem. Jeśli krytyk chwali Nałkowską, to za „przezwyciężenia”. W jej książkach po 1918 roku (Hrabiego Emila pomija) razi go obecność autorki w świecie przedstawionym, w rolach protekcjonalnej sąsiadki, turystki, mieszkanki prowincjonalnego miasta „zbierającej plotki i zwierzenia” oraz „litościwej społeczniczki i filantropki”, co go szczególnie brzydzi (136).

Uznając, że cała droga twórcza Nałkowskiej jest „dramatycznym przezwyciężaniem samej siebie" (cyt. 137), rezultat - jak wyżej - przedstawia w karykaturze. Tak samo jak Granicę. Krytyk po prostu unicestwia tę powieść i postawę pisarki w katalogu najcięższych zarzutów: o brak moralności, o potraktowanie świata nędzy jako sposobu na „ostateczne przełamania narcyzmu, skompromitowanie i przekreślenie dawnej siebie”, jako „estetyzm à rebours” (cyt. 137). Przepisał z niego te inwektywy rówieśny druh, Gustaw Herling-Grudziński, w zdumiewającej recenzji Medalionów, obrazie całkowitej głuchoty na treść i wymowę tego świadectwa.

Autorka szkicu nie próbuje nawet dociec przyczyn tak bulwersującego likwidatorstwa, jakie zamanifestował Fryde, orzekając, że z Granicy zionie „przeraźliwa pustka, pustka świata bez wartości" (cyt. 137). Nie pyta, skąd w ogóle brutalny atak krytyków młodego pokolenia (Fryde, Wyka, Troczyński, Miłosz z jego napaścią na Niecierpliwych!). Wobec dzisiejszej wiedzy o drogach rozwoju literatury XX wieku ich ówczesne zarzuty i potępienia zaliczyć można do kolekcji jaskrawych 
pomyłek krytyki. Młodzi, przeważnie lewicowi, drapieżni następcy „starych”, establishmentu literackiego, głosili „aktywizm”, oczekiwali jawnych deklaracji politycznych, leżących na wierzchu dzieła, oraz zaangażowania społecznego. Jakie uprzedzenia czyniły ich ślepymi na krytycyzm Granicy i świat jej wartości? Niewątpliwie można tu wyczytać kierowany do kobiety pisarki stanowczy zakaz bycia sobą, zwłaszcza do kobiety sukcesu, i wyraźne nieprzygotowanie na jej inny, nowatorski „idiom”.

Badaczka wraca jeszcze do Gilbert i Gubar, tym razem do słynnej ich książki The Madwoman in the Attic (Wariatka na strychu), analizującej powieśc wiktoriańska. Stąd czerpie kolejną ideę: „lęk przed autorstwem”. Znajduje go w cytatach z dziennika Nałkowskiej, będących świadectwem jej ciężkich rozterek przy pisaniu Granicy. Nie wiemy jednak, ile w jej udręce było niewiary w siebie, która nęka każdego artystę wobec ogromu twórczego zadania, a w jakiej mierze „chęć bycia jak inni”, którą sobie wyrzucała, brała się z podświadomego strachu przed patriarchalnym trybunałem.

Krajewska pomija „relacje” z Krleža, którego wpływ ideowy lewicowego pisarza sama Nałkowska uznaje, dodając przecież znaczące słowa: „Oparł się jednak na czymś, co było we mnie istotne i ważniejsze. Jakby darował mi mnie sama jeszcze raz" (1 VII 1933; cyt. 140).

Na koniec autorka przypomina epizod udziału Nałkowskiej w Zespole Literackim „Przedmieście” właśnie w czas pisania Granicy. Odeszła od nich, mimo bliskości ideowej i odwiecznej przyjaźni z Boguszewska, broniąc „literatury i psychologizmu”, jak zanotowała w dzienniku, „przeciw tematyczności proletariackiej i reportażowi [...]" (2 III 1934; cyt. 142). Krajewska tłumaczy owo rozstanie tym, że Zespół uważał za niezbędny warunek przynależności „emocjonalne zaangażowanie po stronie badanych i opisywanych" (142), sugerując tym samym, że Nałkowska warunku tego nie spełniała. Co więcej, podstawienie innego słowa zmieniło treść cytowanego postulatu „Przedmieścia”, nadając przez to równie fałszywy, jak rozmyślnie pejoratywny sens postawie pisarki wobec ukazywanych w Granicy plebejuszy:

nie zdecydowała się ani na uchylenie subiektywizmu, wyrażającego się w odnarratorskich filozoficznych komentarzach, ani tym bardziej na pełną identyfikację $\mathrm{z}$ opisywanym środowiskiem proletariackim. [142; podkreśl. H. K.]

Na czym miałaby polegać „pełna identyfikacja”, nie wiadomo. Pewne jest jednak „emocjonalne zaangażowanie” Nałkowskiej. Opinia Krajewskiej skażona została rozumowaniem Frydego. Kolejne nieporozumienie w tym cytacie to zignorowanie faktu, że Granica jest w znacznej mierze powieścią filozoficzną, nie tylko społeczno-polityczną, i nazywanie tego jej wymiaru „subiektywizmem” stanowi doprawdy gruby błąd.

Krajewska kończy swój szkic słowami: „Syntezą kobiecości i "cudzego" są w jej [tj. Nałkowskiej] przypadku próby poszukiwania prawdziwej siebie” (143). Powiedziałabym raczej: obrony, potwierdzenia siebie, skoro wyznała, że w Granicy ma się „u j a w n i ć prawdziwa” (1 VII 1933; cyt. 140; podkreśl. H. K.).

W sumie szkic Joanny Krajewskiej pozostawia nas w kręgu znanych ustaleń, z lekka powleczonych szminką zagranicznych lektur. Psują odbiór tekstu błędy językowe i stylistyczne: „nasamprzód”, „krytyk demaskuje rezonerstwo wobec 
Stefana Żeromskiego” (127), „autorka Wę̇̇y i róży” (129), „wystapienia programowe swoich kolegów [...] spotkały się z uwagami pisarki [...]" (142) i inne. Gdzie redaktor?

Sylwia Karolak przedstawiła szkic „Granica” $w$ nauczaniu języka polskiego w postaci przeglądu materiałów. Szuka najpierw w recenzjach i opracowaniach powieści wzmianek o sprawach kobiet, bo opinie krytyków stanowiły też wskazówki dla nauczycieli. Znajduje głównie dwa tematy: romans Ziembiewicza ze służącą i wysoce ekspresyjny opis starzenia się kobiet. Niektórzy recenzenci patrzyli na „skandal erotyczny” od strony Ziembiewicza, na łamach „Prosto z Mostu” Witold Turno stwierdzał wręcz, że „proste uwiedzenie dziewczyny”, „przewinienie powszednie”, ,nie znajduje jednak ani naszego przekonania, ani uczucia” (cyt. 151). Krytycy podnoszą również sprawę niespełnionego macierzyństwa „Justysi” lub też „Justynki” (protekcjonalne zdrobnienie nie występuje w powieści), która popycha dziewczynę do zbrodni. Niektórzy pojmują ten gest jako wyłącznie osobisty, bez związku z kontekstem społecznym. Niewielu, i to raczej po wojnie, widzi w czynie Justyny akt klasowego odwetu. Najobszerniej rozwiódł się nad pogwałceniem instynktu macierzyńskiego i cierpieniami poaborcyjnymi kobiety konserwatywny krytyk i pisarz Adam Grzymała-Siedlecki. Uznał ten wątek za najważniejszy w powieści; przejmująco poprowadzony, ,najserdeczniej wyrywa się z chłodnego obiektywizmu dzieła”. Nie bez przyczyny przywołał tu kampanię Boya i Krzywickiej na rzecz świadomego macierzyństwa.

Przeglądając materiały o Granicy, autorka artykułu mimochodem odtwarza z pojedynczych spostrzeżeń niektórych krytyków i badaczy rozległy obraz kobiecej egzystencji w jej wyznacznikach biologicznych, społecznych i kulturowych, jaki stworzyła Nałkowska w powieści. Jego bogactwo i znaczenia nie docierały w całości do wypowiadających się o tym dziele. Dostrzegano i opisywano elementy owego obrazu wybiórczo. Przez długie lata brak było świadomości feministycznej, by je scaliła i - doceniła. Omawiana książka zbiorowa dowodzi, jak trudno o to nawet u feministek. Karolak bada następnie sposób funkcjonowania Granicy w szkole średniej jako lektury obowiązkowej od 1951 roku do dziś. Niekiedy pojawiała się - na krótko - we fragmentach lub jako pozycja do wyboru. Autorka zagląda więc do wskazówek programowych i metodycznych. Do roku 1955 powieść służyć ma, według twórców tych wytycznych, do przedstawienia roli literatury jako „oręża ideologicznego". Granica zatem to wtargnięcie do mieszczańskiej powieści psychologicznej elementów realistycznych, obrazów „rzeczywistej walki klasowej” (cyt. 157).

W latach sześćdziesiątych mówi się ogólnikowo o „rozwoju prozy realistycznej w okresie lat 1918-1939" (cyt. 158), dopiero w programie z 1974 roku pojawia się wielostronna już optyka interpretacyjna: „Społeczna i psychologiczna analiza powieści. Filozoficzna i moralna problematyka powieści. Krytyka społecznej rzeczywistości. Budowa i styl powieści” (cyt. 158). To samo w 1983 roku. Sądzę, że mógł to być efekt zarówno uwolnienia badań literackich od dyktatu ideologii marksistowskiej, jak i tego, że w latach sześćdziesiątych i siedemdziesiątych ukazało się kilka istotnych i nowych interpretacji prozy Nałkowskiej, m.in. Sławińskiego, Czermińskiej, również moja, co wpłynęło na twórców programów dla szkół. Nawiązali też oni w tych latach współprace z Instytutem Badań Literackich PAN. 
Karolak zagląda także do podręczników, publikacji z serii „Biblioteka Analiz Literackich” i do czasopism pedagogicznych. $Z$ „Polonistyki” przywołuje - dla przestrogi? - artykuł Krystyny Leśniewskiej o Granicy z 1950 roku, kliniczny okaz stalinowskiego języka. W 20 lat później ukazał się tamże tekst dotykający najważniejszej sprawy: jak nauczyciel radził sobie z Granica na lekcji. Nic przecież na ten temat nie wiemy. Autor, Antoni Mackiewicz, przytacza opinie uczniów o tym, co dla nich w tej powieści najistotniejsze: tragizm starości, sytuacja porzuconej kochanki. Nauczyciel kierował jednak ich uwagę na „dramat Ziembiewicza” i zwłaszcza na przebieg jego kariery politycznej.

W roku 1979 monografista Nałkowskiej, Włodzimierz Wójcik, w tejże „Polonistyce” bronił jej przed etykieta „literatury kobiecej”. Mackiewicz w piśmie „Język Polski w Szkole Średniej” za rok 1994/95 przypomniał „sąd nad Justyną”, który odbył się 10 maja 1936, i proponował analogiczna inscenizacje na lekcji. Miał to być przejaw zainteresowania sprawą kobiet.

Temat kobiecy zarówno Wójcik, jak Zaworska w „Bibliotece Analiz Literackich” lokuja we wczesnych powieściach autorki Granicy. Karolak sprawdza też inne jeszcze artykuły, wstępy i posłowia oraz tematy maturalne z Granicy aż do 2007 roku i nie odnajduje w nich problematyki stricte feministycznej. W podsumowaniu stwierdza, że konserwatywna szkoła nie kwapi się do jej podjęcia i „dynamiczny rozwój krytyki feministycznej" do niej nie dociera (167). Autorka widzi w tym odbicie stanu świadomości społecznej i stosunku kół rządzących do tej kwestii.

Dynamiczny rozwój krytyki feministycznej objął też teorię przekładu. Ursula Phillips, zasłużona tłumaczka i znawczyni literatury polskiej, współredaktorka zbioru Polish Literature in Transformation (Berlin 2013) tłumaczy ostatnio książki Nałkowskiej: Choucas (2014) i Granice (2015), pracuje nad powieścią Niecierpliwi. W artykule Granice przekładu: „Granica” Zofii Nałkowskiej jako tekst feministyczny przedstawia dzieje feministycznej teorii przekładu, która powstała w latach osiemdziesiątych XX wieku, a w następnej dekadzie poddana została szerokiej dyskusji i po niej się nie obroniła. Ma jednak tę zasługę, że unaoczniła iluzoryczność „przezroczystego” tłumaczenia i zasadniczy wpływ „interpretacji”, jakiej translator, świadomie lub nie, poddaje oryginalny tekst. Zależy ona od upływu czasu między powstaniem utworu a jego przekładem, oraz od osobistej wrażliwości i przekonań tłumaczącego.

Phillips przywołuje na dowód tłumaczenie Drugiej płci (1949) Simone de Beauvoir dokonane przez Howarda Parshleya w 1953 roku. Jego słowna interpretacja sprawiła, że „feministyczny wydźwięk” książki „został [...] rozmyty, a może nawet stał się niewidoczny dla anglojęzycznych czytelników [...]" (172). Z drugiej strony, proces translacji może wydobyć elementy tekstu dotąd zaniedbywane lub zniekształcane. Należy wreszcie odkryć prawdę, że tłumacz nigdy nie jest „neutralny".

Autorka demonstruje to zagadnienie na próbkach własnego przekładu fragmentu Granicy, sławetnego „kongresu czarownic” na imieninach pani Kolichowskiej. Poprzedza zaś ostrzeżeniem, które powinno zainteresować redaktorkę i autorki omawianej książki zbiorowej. O jakim feminizmie możemy mówić przy powieści z lat trzydziestych, skoro dziś ten ruch jest tak pluralistyczny, a zalicza się do niego także aktywistki prokobiece, krytyczki nierówności społecznych, nie manife- 
stujące ideologii feministycznej. Phillips pojmuje feminizm Nałkowskiej w Granicy jako najogólniej „wrażliwość polityczną”, a nie przynależność do ruchu prowadzącego do uwidocznienia cierpień i dyskryminacji społecznej kobiet z powodu ich płci. Phillips podkreśla, że ten „feminizm” pisarki ma formułę znacznie szersza, obejmuje „cierpienia kobiet ze wszystkich sfer społecznych, [...] rozumiane nie tylko jako bytowe nierówności, ale także na poziomie egzystencji i ciała w seksualnych związkach z mężczyznami, w małżeństwie” (173-174).

Tę listę trzeba wydłużyć o problem macierzyństwa i związków z matką czy ojcem oraz zależności: pracownica i pan/państwo. Wspomniałam o tym „całościowym” obrazie sytuacji kobiet w powieści, omawiając pracę Sylwii Karolak.

Pokaz swojego warsztatu translatorskiego poprzedza Phillips zwięzłą informacją o narodzinach (w Kanadzie) szkoły feministycznego przekładu. Przedstawiając tezy głównych jego teoretyczek, informuje zarazem o swoich wyborach i strategiach translatorskich. Zalicza do nich także opatrywanie przekładu wstępem i przypisami, w których można wskazać na aspekty feministyczne utworu. Ważna jest wzmianka o tym, że szukając odpowiednika stylu Nałkowskiej w literaturze angielskiej, Phillips wybrała język Virginii Woolf. Zestawiano już te dwie pisarki.

Omówienie taktyki przekładowej zastosowanej wobec wspomnianego fragmentu tłumaczka poprzedza wnikliwym i subtelnym odczytaniem jego znaczeń. Przedstawia następnie dwie wersje przekładu, objaśniając sens użycia wybranych słów i ich możliwe konotacje „genderowe”. W pełni ocenić wartość tych dwóch wersji jest w stanie tylko świetny znawca angielszczyzny. Tekst Ursuli Phillips wyróżnia się poziomem, kompetencją i kultura w tym nierównym zbiorze.

W artykule Sylwii Panek „Wybiła godzina kryzysu dyskrecji”. Krytyk o pisarce powraca Karol Irzykowski, przywołany na początku książki jako recenzent wczesnych utworów Nałkowskiej. Tu występuje jako diagnosta a) pisarstwa kobiet, b) literatury polskiej Dwudziestolecia w ogólności. Zaczęło się w 1928 roku od ataku Ireny Krzywickiej na metaphoritis literatury kobiecej i na inne jej grzechy. Do sporu włączyli się mężczyźni, też objęci diagnozą Krzywickiej jako pierwotne źródło zła (Żeromski, Kaden-Bandrowski). Zabrał głos Irzykowski, ogłaszając, że piszące kobiety wyjaskrawiaja niedobre intencje całej literatury. Do nich zalicza autobiografizm (nazywa go niedyskrecją), który zarzuca literaturze kobiet, również Nałkowskiej.

Widzę osobliwy paradoks w tym, że owe zarzuty ogólne mają źródło autobiograficzne, pilnie skrywane, i że sam Irzykowski czynił wątki życia prywatnego (np. choroba i śmierć córki Basi) tworzywem swoich utworów literackich. O tym Panek nie wspomina. Nie wiem, czy zachowały się listy Irzykowskiego do Nałkowskiej, ,,w których zwierzał się jej ze swojego młodzieńczego uczucia do Erny Brandówny [...]”, jak podaje Panek (193). Wiadomo za to, że dał jej jedynej do czytania swój sekretny dziennik pisany w 1898 roku dla narzeczonej, owej Erny, której nigdy go nie pokazał.

Irzykowski tak przecież ocenił te wyznania (już w czasie okupacji):

Osiagnąłem w [...] tym dokumencie tak wysoką temperaturę, takie piękności wypłynęły mi spod pióra - oprócz brzydoty i głupoty - że sam sobie zaimponowałem [...]. Pałuba narodziła się właśnie na podstawie tego pamiętnika [...]. Ta busola towarzyszyła mi np. także przy rozważaniach literackich, gdy domagałem się owej najwyższej miary, gdy [...] u początków twórczości kładłem taki [...] stan szczerości 
i jasności z sobą, takie napięcie uczucia i intelektu, jakie wynika z pamiętnika albo faktycznie posiadanego, albo wciąż pisanego, choćby w myśli ${ }^{7}$.

Rozwikłać tę sprzeczność w prywatnych, utajonych i oficjalnych poglądach, to byłoby zadanie. Być może, Irzykowskiego bardziej niż zlekceważenie jego uczuć bolało to, że Nałkowskiej nie olśniła dostatecznie jego wielkość i wyjątkowość talentu oraz ducha zawarta w intymnej spowiedzi. Pisarka odniosła istotnie silne wrażenia $z$ lektury, ale nie zaspokoiła $w$ pełni jego oczekiwań, nie zapłonęła uwielbieniem. Irzykowski wyznał w dzienniku: „po doświadczeniu z Z. N. - jedyną, która czytała ów pamiętnik, nabrałem niewiary w ludzi”"

Może „niedyskrecje”, jakich się obawiał, jakie tępił w literaturze i jakie odczytywał w kolejnych powieściach Nałkowskiej, bolały go dlatego, że dotyczyły innych mężczyzn w jej życiu, nie jego? Zostawmy jednak te dociekania, czytamy bowiem w przypisie 11 do artykułu Panek, że poświęciła ona osobny tekst prywatnym relacjom krytyka i pisarki (193).

Wobec tej powtórki z Irzykowskiego rodzi się jedno, zasadnicze zastrzeżenie: brak tu refleksji nad trafnością uogólnień krytyka. Szczególnie tych, które z analizy utworów Nałkowskiej przenosił do obrazu literatury kobiet lub literatury tout court. Czy jego postulat sztuki, której obowiązkiem ma być „budowanie ideałów i korekta rzeczywistości”, nie jest cokolwiek wątpliwy? Irzykowski dezawuuje hasło „autentyzm” jako wezwanie do „opisywactwa” rzeczywistości. Autentyzm był propozycja poetycka Stanisława Czernika na początku lat trzydziestych XX wieku, a także funkcjonującym w krytyce terminem, zresztą importowanym, określającym nowe tendencje w prozie europejskiej. Irzykowski zaś „autobiografizm, autentyzm, autoreportaż” nazywał „zachodnimi nowinkami”.

Panek pisze: „autentyzm, którego Nałkowska staje się teoretyczką przede wszystkim dzięki głośnemu tekstowi Pisana rzeczywistość [...]" (196). Drobiazg może, ale Nałkowska używała tam terminu „autentyczność” (tak samo w 1929 roku, w szkicu $O$ sobie), czyli cecha, a nie prąd czy kierunek. Irzykowski zniekształca myśl Nałkowskiej, ale Panek nie łapie go za rękę. Tak samo „nabożna badawczość” była dla Nałkowskiej postawą, nie równoważnikiem „opisywactwa”.

Osobna jest sprawą ciagłe insynuowanie Nałkowskiej przez Irzykowskiego, powtarzane bezmyślnie do dziś, relatywizmu etycznego. Dla krytyka to „łatwa rezygnacja z moralnego osądu postaw i bohaterów”, gdy uprawia się „widzenie dusz od wewnątrz" (196). Nałkowska brała lekcje u Dostojewskiego, a Irzykowski zdaje się walczyć z własnym wyposażeniem duchowym, egzorcyzmując je w imię... realizmu? konstruktywizmu? „korekty rzeczywistości”? Jak w socrealizmie? Jakby nie widział, iż cała europejska literatura jest po stronie Nałkowskiej. Jego szarża przeciw „kryzysowi dyskrecji” i „pamiętnikarstwu” to założenie, że literatura ma zakaz wstępu do pewnych rejonów człowieczeństwa i że biografia artysty nie może być źródłem jego fikcji. A przecież jest od wieków.

Po tych pretensjach krytyka niemal zaskakuje nas pochwała dla Hrabiego

$7 \quad$ K. Irzykowski, Notatki z życia, obserwacje i motywy. Wybór A. Dobosz. Wstęp S. Kisi elew s ki. Warszawa 1964, s. 445. 
Emila i Romansu Teresy Hennert, a także jego przywołanie Nałkowskiej, gdy poruszając ogólniejsze problemy literackie, mówi o niej „pisarka społeczna”, „powieść społeczna”.

W sumie jednak formuła ogólną na twórczość Nałkowskiej jest dla Irzykowskiego literatura kobieca, czyli emanacja kobiecej bierności w opozycji do aktywizmu mężczyzn. Pisarstwo kobiet nie ma jakoby właściwych sobie cech, tylko wyjaskrawia to, co w literaturze - według niego - niepożądane. Gdyby więc postawić kropkę nad i, znaczyłoby to, że mimo uznania dla niektórych osiągnięć artystycznych Nałkowskiej ciągłe z nią polemiki sprowadzają jej twórczość do kobiecego, społecznie niewydolnego gatunku, odtwórczego, nie twórczego, do „opisywactwa” w braku nowych idei. Mężczyźni, peroruje Irzykowski, nawet wychodząc od konwencji pamiętnikarskiej, zachowują wobec niej postawę niezadowolenia, a więc czynną, i przekształcają wyjściową konwencję w nowy gatunek, powieść „skrycie biograficzna”, jak Jan Krzysztof Romaina Rollanda, przemieniaja w „otwarcie autobiograficzna”, „do czego by kobiety same nigdy nie doszły” (cyt. 204). Tako rzecze Irzykowski.

W końcu jednak Sylwia Panek jak najsłuszniej dystansując się od początkowej sugestii o „fobii odtrąconego adoratora” (204), trafia w sedno, odnosząc tezy krytyka o pisarstwie Nałkowskiej do jego stereotypowych przekonań na temat płci. Jednakże brak głębszej polemiki $\mathrm{z}$ autorem Beniaminka i kompozycyjny chaos tekstu Panek osłabiaja jego wymowę.

Natomiast obszerny szkic Ewy Graczyk „Nie tylko słowa”. O inny obraz modernizmu $w$ Polsce ma energię polemiczną i skutecznie trafia nią w problem kluczowy dla feministycznych założeń tej książki. Mówi o tym, jak powstające dzisiaj syntezy historycznoliterackie, ustanawiajace nową periodyzację i hierarchię, utrwalaja $\mathrm{w}$ istocie stary, androcentryczny punkt widzenia. Ignorują dorobek twórczy kobiet i jego rzeczywiste znaczenie w obrazie literackiej nowoczesności.

Graczyk posługuje się terminem „modernizm” w nowym znaczeniu, przejętym z krytyki anglosaskiej i już utrwalonym w polskich badaniach literackich. Jest ono dużo szersze niż w fundamentalnej monografii Kazimierza Wyki, gdzie chronologicznie sięgało 1914 roku, obecnie zaś trwa do lat sześćdziesiątych XX wieku, po których nastaje postmodernizm... Autorka odnosi się do serii wydawniczej „Modernizm w Polsce”, liczącej już 45 tomów. W tym zwierciadle „nowoczesności” dostrzega tradycyjne, nienaruszone hierarchie „genderowe”, „obywające się właściwie bez pisarek" (209). Stwierdza, że wysiłki krytyki feministycznej, ustalającej, poprzez odkrywczą i właśnie nowoczesną lekturę, miejsce kobiet piszących, idą na marne. Ewę Graczyk przygnębia uporczywość tej lekceważącej eliminacji, która fałszuje obraz literatury. Badaczka widzi w tym analogię do „szklanego sufitu”, którego kobiety nie mogą przebić w życiu społecznym.

W słusznym gniewie na arogancję i lenistwo myślowe krytyków i historyków literatury autorka stara się uwidocznić niektóre skutki emancypacji literackiej, czyli tłumnego wtargnięcia kobiet do literatury XIX wieku, a tym bardziej później, ponadto wskazać na zaniechania literaturoznawców, pozostawiających bez weryfikacji przestarzałe sądy, utarte pojęcia.

Są to pomysły z różnych kieszeni, by tak rzec. Graczyk zaczyna od wskazania roli pisarek w rozwoju powieści czy też socjologicznych wyznaczników ich skłon- 
ności do wyboru tego „gatunku długiego trwania”. Był to sposób na uzyskanie trudnej równowagi między relacją z rosnącym w liczbę „ludem czytelniczek” a mizoginicznymi krytykami, „którzy decydowali o ich [tj. pisarek] przetrwaniu w kulturowej pamięci” (212). Taka sytuacja kobiet piszacycych przesądzała według badaczki o sięgnięciu po narrację w mowie pozornie zależnej, która miała pełnić jednocześnie funkcję ekspresji kobiecego podmiotu, jak też swoistej osłony - dodajmy: maskującej identyfikację narratorki-autorki $z$ jej bohaterkami.

Graczyk podaje jako wyrazisty przykład upodrzędnienie miejsca Nałkowskiej w historii literatury wobec wyniesienia Gombrowicza-nowatora, choć „to ona jest autorką wielu konceptów i sformułowań, które uważamy ze wynalazek Witolda Gombrowicza" (208). Ma tu na myśli moje ustalenia w artykule Natkowska - prolegomena do Gombrowicza (1984), gdzie po raz pierwszy zestawiłam oboje pisarzy. Wówczas, w fazie euforycznego odkrywania wyklętego „emigracyjnego” twórcy, przyjęto moje tezy sceptycznie i bez konsekwencji.

Nałkowska staje się tu też przykładem szczególnej roli mowy pozornie zależnej w tekstach kobiecych. Graczyk sądzi, że jej użycie ma podtekst lękowy, zastępuje niestosowną u kobiet, a tak oczywistą u „trzech muszkieterów” Nowoczesności: Witkacego, Schulza, Gombrowicza, zwycięską swobode podmiotu w wyrażaniu swego Ja narracją w pierwszej osobie. Graczyk twierdzi więc, iż poza debiutem, powieścią Kobiety, Nałkowska również skrywa się za mową pozornie zależną. Wie ona - pisze Graczyk - że:

kobiece ,ja” w literaturze zawsze jest o krok od konwencji niewiarygodnego narratora, [...] wlecze za sobą w głąb tekstu drugorzędność, nieważność społecznej i egzystencjalnej sytuacji kobiety. [212]

Zapewne intuicja autorki wskazuje na coś istotnego, ale wymagającego „chirurgicznej precyzji”. Jeśli bowiem Nałkowska już w drugiej powieści odstapiła od zwycięskiego nietzscheańskiego indywidualizmu, który miał wyzwolić kobiecość spod władzy mężczyzny, to czy była to oznaka dojrzewania, czy rezygnacji? Ujarzmienia przez mężczyznę w małżeństwie? Czy nie dlatego wzdychała w dzienniku:

Ach, jaka harda i mocna byłam, gdy byłam młoda. Kobiety i jeszcze Ksiażę - co tam młodości i pychy, jaka odwaga i upojenie sobą. To była cała wartość mojej literatury, chociaż chwalono mi głównie język i artyzm. [7 XI 1910 ${ }^{9}$

Ewa Graczyk, słysząca w męskim Ja pewną siebie podmiotowość, przecenia chyba genderową wyższość tego zaimka. U Schulza i Witkiewicza nie był ekspresją zwycięskich psychik, a Gombrowicz uczynił z Ja maskę i zbroję. Jeśli zaś narracyjne Ja u kobiet miałoby tak cenną i terapeutyczna wartość, to skąd bierze się niemilknący i $z$ uporem odgrzewany również przez badaczki spod feministycznego znaku - jak w tej właśnie książce! - koronny zarzut narcyzmu, egocentryzmu, subiektywizmu? Wytykany nawet Granicy, gdzie Ewa Wiegandt widziała go w aforystycznej, „mądrościowej” dominacji narratora. Graczyk nie zastanawia się nad sensownością tej dziwnej pretensji, płynącej wprost $\mathrm{z}$ męskiego stereotypu kobiecości. 
Hipoteza lękowej genezy częstego użycia mowy pozornie zależnej w pisaniu kobiecym wydaje się jednak wątpliwa. Ten typ narracji, pradawny zresztą, choć dopiero w XX wieku rozpoznany, był mocno ugruntowany w literaturze światowej i związany z technika „punktu widzenia”. Nie osłaniał, lecz uwydatniał zbliżenie czy wręcz identyfikację narratora $z$ postaciami. Był też szeroko używany przez mężczyzn, Kaden-Bandrowski stosował go tak samo jak Helena Boguszewska - a to nazwisko u Graczyk nie pada wcale! - i jej partner życiowy oraz literacki, Jerzy Kornacki. To mistrzowie tej techniki, manifestującej bliskość, utożsamienie z opisywanym światem, przy zachowaniu stanowiska sprawozdawcy i sprawcy.

Pospieszne uogólnienia i wyczuwalne kalki z książek zachodnich feministek, które przecież operują na materiale swojej historii i kultury, osłabiają wartość namiętnych i w ogólnym kierunku słusznych filipik Ewy Graczyk.

Nie ma więc jasności, czy upodrzędnienie pisarek - w szerokiej formule - „modernistycznych" w recepcji i w dzisiejszych syntezach polonistycznych wynika rzeczywiście z ich cech, według Graczyk konstytutywnych: lękliwości osłaniającej się mową pozornie zależna, wybierania techniki realistycznej (brak awangardowych), „psychologizmu” i częstej postawy lewicowej.

Z entuzjazmem przyklasnę przelotnemu, acz ważnemu dezyderatowi Graczyk, by wreszcie zrekonstruować i przewentylować pojęcie „psychologizmu” jako specjalności kobiet-pisarek. W PRL-u to słowo było polityczną inwektywą, w Dwudziestoleciu zaś łączono je $\mathrm{z}$ relatywizmem oraz $\mathrm{z}$ rozchwianiem osobowości jednostki, co rodziło lęk przed wieloznacznością psychik, odkrytą na przełomie wieków. A przecież Dostojewski! W końcu proustowski przewrót to właśnie ogląd rzeczywistości poprzez świadomość bohatera. Świat i człowiek stracili już wymarzona stabilność, a literatura powiedziała to głośno. Powieść psychologiczna stała się równoznaczna $z$ powieścią nowoczesną.

Graczyk uważa, że nośnikiem kobiecego upodmiotowienia była powieść realistyczna, sagi rodzinne itp. Jednak nowatorstwo nie sprowadza się tylko do ekspresjonistycznej groteski i do literackich „samców alfa” jako zuchwałych fantastów i eksploratorów nowości. Powieść przeobrażała się na wiele sposobów - wymieńmy choćby powieść-esej, powieść strumienia świadomości czy prozę dokumentarna, inspirowaną reportażem i gatunkami autobiograficznymi. To właśnie Nałkowska chciała powiedzieć w artykule Pisana rzeczywistość.

Galopada polemiczna Ewy Graczyk zwraca ją nagle w boczny korytarz dygresji o innym przykładzie amnezji badaczy modernizmu. Eliminuja oni mianowicie literaturę „klęski, wstydu i bólu” oraz „utopii Polski”, czyli pisarstwo Żeromskiego, Reymonta, Wyspiańskiego i Zapolskiej. Dalej autorka zarzuca twórcom syntezy modernizmu, że nie korzystają z myśli „postkolonialnej”. W metaforze „utopii Polski” lokuje Graczyk zarówno romantyczny polski mesjanizm, jak i wizję komunizmu. Oba łączy sytuacja zniewolenia: zaborów z jednej, skolonizowania przez ZSRR $z$ drugiej strony.

Po tej pospiesznej dygresji autorka wraca do sprawy kobiet i układa manifest ideowy, zagrzewajacy lud kobiecy do boju. Uważa, że

nasze kobiece poruszenie jest inne niż tamto narodowe, a jednak jakiś rodzaj rewolucyjnego marszu dla nas, w nas, ciągle trwa; jakaś ciągłość niepokoju jest zachowana: nie mamy tego samego zdania, tych samych interesów, co akademicy instalujący pospiesznie tradycyjny dyskurs. [220] 
Ostatnia partia tekstu pisana jest gorączkowo, na przyspieszonym oddechu, już nie odnosi się tylko do literatury, jest emocjonalnym apelem i wizją uciskanego kobiecego ludu, tu zwanego (za zachodnimi lekturami) „podmiotami problematycznymi”. Użycie całej siatki terminów z drugiej ręki pozwala autorce stworzyć wirtualny obraz „akademików” wycinających z historii literatury klęskę i niewolę, ,jakby wcale ich nie było" (220), gdyż chcą należeć do obozu zachodnioeuropejskich zwycięzców. Graczyk nie przedstawia jednak dowodów na taką anihilację doświadczenia historycznego Polaków w dzisiejszych pracach polonistycznych.

Twierdzi natomiast, że gdyby postrzegano kulturę polska jako jednocześnie modernistyczną i skolonizowaną, badacze zaczęliby myśleć o sobie jako o podmiocie podporządkowanym (mającym za sobą przeszłość niewoli, traumę ekstremalnych doświadczeń zbiorowych i rodzinnych), a wówczas poczuliby i zrozumieli położenie innych „podmiotów problematycznych”: „feministycznych, genderowych, queerowych, postkolonialnych" (220). Zauważmy pewną rozbieżność: raz zachodnie prądy myślowe robią u nas złą robotę, pchają do wyrzeczenia się własnej historii, a raz są dla autorki nieustannym punktem odniesienia, nowym językiem, olśnieniem światopoglądowym do tego stopnia, że i ona porzuca lokalny zespół pojęć kulturowych. Zachęca bowiem kolegów badaczy do włączenia się w „światową postkolonialną debatę" (221) z przywróconym bagażem swojskich doświadczeń.

Autorka wzywa na koniec czytelniczki, by tworzyły „utopijne wspólnoty wzrastających podmiotów" (221). Przypomina dla kurażu i przestrogi szeroki sprawczy udział kobiet w opozycji i fakt późniejszego, po 1989 roku, odesłania ich do domu i wtrącenia w anonimowość. Mówi kobietom: „Nadal więc, choć inaczej, jesteśmy wezwane” i dlatego powinnyśmy „odnawiać [...] pakty utopijnej lektury” (223). Utopia to dla Graczyk stan „oczekiwania na coś więcej”, który zapobiega „odrętwieniu, a czasem zapaści niezbędnych do życia funkcji lekturowych” (224). „Lektura” jest tu metaforą koniecznego „odnawiania znaczeń”, szukania tego, co nie leży na powierzchni tekstu (jak mówi teoria écriture féminine).

Jest to, jak widać, wywód publicystyczny, „skaczący po tematach”, w którym Nałkowska stanowi tylko chwilowy punkt zaczepienia. Jednakże, gdyby pójść za logiką dezyderatu Graczyk, to adeptki krytyki feministycznej więcej zrobiłyby dla sprawy, gdyby uwidoczniły znaczenie dzieła Nałkowskiej w obrazie literatury XX wieku i zasługi tej autorki dla feminizmu, niż uprawiały wiktymologię, biadając nad nieobecnościa pisarek w syntezach modernizmu. A co gorsze, dokonywały zbiorowej (w ramach „siostrzeństwa”?) egzekucji na jednej z nich.

Po żarliwym i sprawnie napisanym, choć dyskusyjnym manifeście Graczyk, artykuł Danuty Dąbrowskiej Istnieć $w$ sobie, żyć $w$ historii. O „Dziennikach” Zofii Natkowskiej wydaje się nie tylko „komedią omyłek”, ale i „dramatem nieporozumień”. Tytuł wskazuje na arbitralnie narzuconą na biografię i diarystykę pisarki rzekomą dychotomię: istnienie-życie. Tekst jej jasno nie definiuje, a oparta na niej egzegeza Dzienników obnaża infantylny wręcz, naiwnie harcerski, „czytankowy” desygnat tego podziału. Pobrzmiewa w nim siłą rzeczy ton moralnej oceny, przedłużenie pretensji o narcyzm, egocentryzm itd.

Nieporozumienie wstępne wynika i tutaj z niewiedzy o istocie gatunku „dziennik intymny” i braku dyspozycji do prawidłowej jego lektury. Dzienniki Nałkowskiej nie są kronika jej życia, dziejów kraju i świata wokół ani też pełnym zapisem 
jej świadomości i poglądów. Można je rekonstruować łącznie z twórczością, ale Dąbrowska odcina dzieło od diarystyki, jakby należały do dwóch innych osób.

Cóż więc znaczy „żyć w historii”? Autorka w tekście zamienia to na „uczestniczyć”, czyli co? Być żołnierzem, politykiem, działaczem społecznym, rewolucjonistą, sprawcą historii? Czy człowiek, którego biografia obejmuje rewolucję 1905 roku, pierwszą wojnę światową i walkę o niepodległość, a w rodzinie ma on zaangażowanego społecznie uczonego i publicystę oraz bojownika irredenty, legionistę Piłsudskiego, człowiek, który zaznał wzlotów i upadków nowiutkiego wolnego państwa i współtworzy jego instytucje kulturalne - uczestniczy w historii? A potem staje się ofiarą Historii „spuszczonej z łańcucha”, jest świadkiem klęski państwa, bestialskiego terroru okupanta, dwóch powstań, Zagłady, dookolnej śmierci oraz zniszczenia, głodu, chłodu i bezdomności - żyje i uczestniczy w historii czy nie? Aż nudno i śmieszno przywoływać te oczywistości.

Dąbrowska niby to wie („Życie Nałkowskiej przypada wszak na okres burzliwych przemian” itd.), ale orzeka, że „na pewno nie są to w jej zapiskach tematy główne” (228). Wyciaga $z$ tego wniosek, że „dla pisarki najważniejsza jest ona sama”, że to jakby „przyglądanie się nie tyle historii, ile sobie w historii” (229). Ależ do tego właśnie służy dziennik intymny! Do rozmowy z sobą, do autokomentarza, bez żadnych zobowiązań wobec publiczności i własnej roli społecznej!

Dziennik osobisty to dzieje osobowości, schronienie dla duszy, a nie rejestr epoki. Kategoryczne uogólnienia Dąbrowskiej świadczą też o bardzo powierzchownym kontakcie z dziennikiem i utworami Nałkowskiej, z jej poetyką skrótu, lapidarnej formuły, aluzji. Ona s o bi e nie musi referować zdarzeń. Do tego autorka szkicu ignoruje treści dziennika, które kłócą się z jej tezą. Przedstawiona w szkicu postać Nałkowskiej-diarystki jest konstruktem Dąbrowskiej, która wciąż ogłasza rozmijanie się oryginału z pożądanym wzorem, naiwnie wyobrażonym, i stygmatyzuje te odstępstwa.

Humorystycznie wręcz brzmia, w kontekście feministycznych założeń całej książki, pretensje Dąbrowskiej o „celebrowanie własnej kobiecości” przez pisarkę, bez dowodów. Sufluje jej „przekonanie, że to właśnie mężczyźni przynależą do porządku historii, kobieta [...] jest tworem ahistorycznym” (dowody!) albo znów, za Arletą Galant, powtarza, że mężczyzna to zwierzę, które instynkt pcha do walki (229), co jest bardzo bałamutnym odczytaniem tekstów Nałkowskiej o wojnie.

Dalej zaś Dąbrowska stwierdza, że kobieta jednak „w tym ujęciu [?] staje się w pewnym sensie [?] wytworem kultury”, uwięzionym w konwencjach społecznych, zatem Nałkowska stara się je przekroczyć i zadając sobie przymus (?) „wkracza w [...] męski świat” (229). Dąbrowska, słabo rozeznana w materiale, po prostu zmyśla. Sugeruje, że owa „celebrowana kobiecość”, pasywna (uwaga: Weininger!), niechętna „uczestnictwu” i historii jako takiej, określa osobowość pisarki i jej odbicie w Dziennikach:

stale obecny jest w nich bowiem rytm wchodzenia, zdobywania publicznej przestrzeni i wycofywania się, ucieczki [?], która ma ocalić owo kobiece ,ja”, jego własny sposób istnienia i przeżywania. [229]

No proszę, czegośmy się doczekali! Kobiecość jako wina, twór pasożytniczy, społecznie nieprzydatny. Fakt, że Nałkowska jest pisarką, intelektualistką, osobą publiczną $z$ racji rozmaitych funkcji społecznych w życiu kulturalnym, czego nie- 
zliczone ślady zostały w jej dzienniku, nie ma dla Dąbrowskiej znaczenia. Cytaty, którymi usiłuje ona zilustrować swoje tezy, ujawniaja jedynie, że kompletnie ich nie rozumie. Nie odróżnia też stosunku do historii od uczestnictwa w niej.

Czy naprawdę trzeba tłumaczyć, że pisarka, która widzi całkowitą swoją, jako jednostki, bezsilność wobec tego, co, jak notuje: „odbywa się poza mną i bez mego udziału w układzie żywego świata" (8 I 1932; cyt. 230), a mówi o Europie lat trzydziestych, potem zaś jako cywil, na którego spada kataklizm wojny, klęski, terroru, zniszczenia i śmierci, ma powody, by postrzegać „uczestnictwo” w historii jako gwałt? Dąbrowska nie bierze też pod uwagę lewicowego światopoglądu pisarki, który określa jej krytyczny i sceptyczny sąd o biegu dziejów. Czy to, co dzieje się w dzisiejszej Europie - na Ukrainie, w Rosji, Syrii, Paryżu par exemple - nie dzieje się poza nami i bez naszego udziału, choć może na nas spaść?

Jak dalece tekst Dzienników jest nieprzejrzysty dla Dąbrowskiej (i cytowanej przez nią Galant), świadczy interpretacja dwóch fragmentów z zapisków wojennych, przywołanych na s. 230-231. Pierwszy (,przestępstwem jest sama chęć izolacji” itd.) nie odnosi się do relacji z matką, tylko z siostra, która narzucała Zofii różne domowe restrykcje. Drugi cytat (,uchylić się od tej psychozy, [...] p o zo s ta ć s o b a!!") dotyczy zachowań Gustawa Zahrta, który przebył powstanie w Warszawie i po powrocie bardzo źle znosił uchodźców koczujących w jego domu. Wreszcie fragment użyty przez Galant: „fakty są trudne i muszą być wyłączone” (cyt. 231) nie oznacza odepchnięcia wydarzeń wojny, odwrócenia się do nich plecami, tylko konieczność konspiracji, niemożność wpisywania w dziennik zbrodni okupanta, działań odwetowych podziemia czy wiadomości $\mathrm{z}$ frontów wojny zdobywanych z „gazetek”, nasłuchu radiowego czy pogłosek. Ezopowy język Dzienników staje się, jak widać, dla późniejszych generacji coraz bardziej nieczytelny mimo „podpowiedzi” edytorki. Tylko że badaczki powinny umieć czytać historię...

Uporczywość ciagłego tropienia w zapiskach Nałkowskiej jej rzekomego rozbratu z historią przekłada się na wyławianie zwrotów świadczących o postawie „spektatora" i słuchacza - a zawsze ma to być przeciwieństwem uczestnika! Porównania do teatru - sama Dąbrowska używa zadawnionego określenia „teatr wojenny” - sa w pospiesznej notatce dziennika ekwiwalentem zaskoczenia, poczucia widowiska w pierwszych godzinach i dniach wojny, a także, w późniejszych zapiskach, przeżywania wydarzeń na podstawie cudzej relacji, „z drugiej ręki”. Autorka z odległego czasu domaga się od pisarki ciągłej deklaracji i autocharakterystyki - widząc w niej stale brak, ułomność, uchylanie się, rodzaj sobkostwa, gdy tymczasem dewiza „zachować siebie w tej grozie” była wyrazem heroicznego cywilnego oporu.

Zdumiewająca jest arogancja wywodów Dąbrowskiej, która chwilami niczego nie rozumie, trzymając się uporczywie ponawianej arbitralnej tezy. Kiedy już nie może nie dostrzec udziału Nałkowskiej w życiu publicznym i jej refleksji o dziejach, to przypisuje to wyłącznie "nadrzędności "ja" i definiuje jako oglądanie świata „z tej szczególnej subiektywnej perspektywy, gdy nie szuka się prawdy o świecie, lecz prawdy o sobie i własnych doznaniach w jego odbiorze" (232)! A jak inaczej odbiera się świat, jeżeli nie przez własne Ja? Dlaczego Dąbrowska zakłada, że pisarka nie szukała prawdy o świecie? Doprawdy, ten tekst wymagałby ciagłego douczania autorki w zakresie wiedzy o Nałkowskiej, o podstawach psychologii i czytania tekstu ze zrozumieniem. 
Natchnieniem Dąbrowskiej jest cytat $\mathrm{z}$ innej publikacji Agaty Zawiszewskiej, która bezrefleksyjnie powiela stereotyp o „narcyzmie” Nałkowskiej, wychodząc od debiutu 19-latki, spisanego jeszcze z pensjonarskiego dziennika, Lodowych pól. Wystarczyłoby przepowiedzieć sobie treści i tematy książek Nałkowskiej, ale Dąbrowskiej wydaje się, że w dzienniku intymnym pisarka zobowiązana jest przedstawić pełny garnitur swoich sądów o świecie (koniecznie bez udziału swego Ja!) językiem dla Dąbrowskiej zrozumiałym. Oczywiście, można i te sądy w dzienniku znaleźć, tylko trzeba umieć czytać.

Autorka szkicu zostawia w końcu trywialne rozważania Zawiszewskiej i sięga po wznioślejsze analogie. Bierze z eseju Camusa Człowiek zbuntowany cytat o dandyzmie romantycznym i jego implikacjach w osobowości. Pojęcie dandyzmu w odniesieniu do Nałkowskiej przywołałam już dawno i w kontekście literatury modernizmu, bo tam miało inne konotacje, bliższe fazie adolescencji przyszłej pisarki. Nawet jeśli hasła Camusa: „Inni są lustrem”, brak Boga, cierpienie samotności, dałoby się i do Nałkowskiej przymierzyć. Jednak Dąbrowska dokonując takiej przymiarki, likwiduje właściwie te analogie. Stwierdza bowiem, że romantycy mieli wielką ideę (ale i Boga, mimo zwady z nim), a Nałkowska jakoby nie ma ani Boga, ani idei, ani nawet wartości zastępczych jak twórczość czy miłość. „Stanowią [one] jednak bardziej przestrzenie okresowych ucieczek niż absolutny wyznacznik egzystencji” (234).

Powiedzieć coś takiego o kobiecie, która pisała nieustannie od 12 roku życia po ostatnie dni przed śmiercią! Dla której niemożność tworzenia w czasie okupacji była ciężkim dopustem, niemal odebraniem tożsamości. A miłość jako ucieczka? Przed czym? Tak bywa, gdy się cudzy koncept naciagga na wybrany nieżyjący obiekt, a nie wychodzi od tekstu twórcy.

Równie sztuczne i nietrafne jest szukanie w dandyzmie źródeł „tendencji do teatralizowania własnego życia, ale także ogólnego postrzegania i opisywania świata jako teatru [...]" (234). To pierwsze bez dowodu, to drugie nadużyte. Dąbrowska projektuje przypadki zwyczajowej frazeologii na osobowość i twórczość Nałkowskiej, nie wiedząc nic o nieprzystawalności tych uogólnień i etykiet do życia i dzieła pisarki. A czy zna dzieło Ervinga Goffmana Człowiek $w$ teatrze życia codziennego?

Mamy rozumieć, że to $\mathrm{z}$ cech charakteru, z przerostu Ego (jakby talent i wybitność nie były $z$ definicji przerostem ego) wynika postrzeganie świata jako teatru, w którym jest się tylko widzem. Zabawna ta sprzeczność $\mathrm{z}$ wołaniem Graczyk o manifestacje kobiecego Ja. Dąbrowska nie pamięta o tym, że odruch natężonej obserwacji, słuch na cudzą opowieść należy do „fizjologii” urodzonego pisarza. Czytając zamieszczone w dzienniku relacje uciekinierów z powstańczej Warszawy, Dąbrowska wyławia skrzętnie każde słowo „teatr” i „dramat”, jakby nie były one najporęczniejszym skrótem dla uwidocznienia oczywistej sytuacji kobiety cywila, poznającej „dramat” powstania i śmierci miasta z drugiej ręki, jako "spektator” i słuchacz, bo pragnącej utrwalić w słowie mękę ludzi i „uczestniczyć” w niej. Czy Dąbrowska nie wie, że tak powstały Medaliony? Z udziału w pracach Głównej Komisji Badania Zbrodni Niemieckich, ze słuchania i oglądania?

Niepojęte są wnioski Dąbrowskiej, że przejmujący reportaż z wrześniowej tulaczki wpisany do dziennika to „tylko” bierne obserwowanie i słuchanie oraz „starania, aby nie zgodzić się na uczestnictwo" (235). Powinna zgłosić się do wojska? 
Czy wciskając się w ziemię na poboczu bombardowanej szosy, by skryć się przed nadlatującym samolotem, „uczestniczy się” czy „odmawia się uczestnictwa”?

Mam wrażenie, że autorka nie pojmuje warunków życia ludzi, cywilów w okupowanym kraju i wciąż usiłuje nagiąć rzeczywistość do swoich tez. Zapisywanie w dzienniku szczegółów codzienności wydaje się jej strategią „odgradzania się od wojennej rzeczywistości” (235). Najwyraźniej nie czytała innych świadectw okupacyjnych. Te „szczegóły”, czyli zimno, głód, utrata domu i dorobku życia, walka o przetrwanie, ze śmiercią możliwą o każdej godzinie, codziennym terrorem i wyzuciem $z$ tożsamości polskiej pisarki i artystki były sednem wojennej egzystencji.

Dąbrowska niby wie, że Nałkowska w dzienniku okupacyjnym posługuje się językiem ezopowym $z$ konieczności, ale kompletnie tego nie rozumie. Powtarza ciagle, że pisarka odpycha od siebie okupacyjną rzeczywistość, również słowa „getto” nie używa, mówi o „tamtych ludziach” (nie! o tych!). Razi niezmiernie ta naiwna pretensja i ta niewiedza. Autorka chyba nie czytała nawet komentarza edytorki, który deszyfruje wiele aluzji pisarki. Choćby zdanie: „Ale nie można wytrzymać myśli. [...] Los tych ludzi daleko, los tych ludzi obok" (28 IV 1943; cyt. 239). Oznacza ono odkrycie grobów katyńskich i śmierć getta w tym samym czasie.

Dąbrowska nie rozumie też, że w dzienniku pewne informacje w ogóle nie mogły się pojawić, bo były zbyt niebezpieczne. Nie tylko getto i Żydzi, ale i różne formy udziału w tajnym życiu kulturalnym, podziemna prasa itp. Blisko 60-letnia Nałkowska, utrzymujacca rodzinę, nie jest żołnierzem AK czy innej konspiracji, ale to, w czym „uczestniczy”, to także demonstracja oporu: udział w tajnych wieczorach i konkursach literackich, w naradzie pisarzy (na zapleczu stołówki literackiej, w prywatnych pokojach jej kierowniczki, pani Goetlowej, w których ukrywają się Żydzi) nad wyjazdem Goetla z delegacją Czerwonego Krzyża do Katynia, gdzie Niemcy odkryli groby polskich oficerów, czy wreszcie starania o ocalenie Brunona Schulza. Wszystko to niosło ze sobą groźbę śmierci.

Wielu wcześniejszych przykładów swego „uczestnictwa” w wydarzeniach dziejowych czy pracach społecznych Nałkowska po prostu nie wpisywała do dziennika lub enigmatycznie o tym napomykała. W komentarzu edytorskim podano fakty, które udało się odkryć gdzie indziej. Dąbrowska się tym nie zajmuje i wciąż nakłada na Nałkowską jakieś swoje nienazwane wyobrażenie o normie czy pożądanym sposobie uczestnictwa w historii. Posuwa się więc do dziwacznej insynuacji: „obca jest jej [tj. Nałkowskiej] [...] idea wyrzeczenia się siebie na rzecz działania dla wspólnego dobra” (241). Tak sobie tę rzecz dziecko Dąbrowska wyobraża?

Nic więc dziwnego, iż wyciąga daleko idące wnioski z konstatacji, że jakoby „nie pojawia się u Nałkowskiej kategoria "my", zawsze jest "ja» i "oni»" (241). Ależ pojawia się, tylko trzeba czytać! Od pensjonarskiej deklaracji przynależności do „ludzi społecznych”, poprzez głębokie poczucie solidarności z obrońcami Brzozowskiego, po niezliczone sytuacje, w których Nałkowska odnajdywała się we wspólnocie „my”. Dąbrowska sięga po zapiski z Września 1939 i nie dostrzega, że w cytowanym przez nią fragmencie przeważa mianownik liczby mnogiej czasownika: jesteśmy, uczyniliśmy, daliśmy, pozwoliliśmy - my naród, my społeczeństwo, my rządzący, my odpowiedzialni za oświecenie narodu. I krzywdę, i winę równocześnie dzieli Nałkowska z tym zbiorowym „my”.

W podsumowaniu Dąbrowska raz jeszcze umacnia się w swej fałszywej tezie, 
podpierając się autorytetem Marii Janion, która „uderza znikomość miejsca poświęconego w Dziennikach "sprawie polskiej"” (cyt. 242). To frazeologia z elementarza romantycznego, którego Dąbrowska się trzyma. Tym razem zauważa słusznie, że Nałkowska nie przynależy do tego porządku, „poszukuje dla siebie odrębnej formuły”, ale o tej odrębności potrafi powiedzieć tylko to, co zawsze: „formuły, której centrum stanowi niepowtarzalne "ja"” (242). To nic nie znaczy. Piłsudski też, jak każdy wybitny człowiek, miał niepowtarzalne Ja i ono z pewnością „stanowiło” centrum wszystkiego.

A może by tak rozważyć to, że Nałkowska proponuje nam nowocześniejszą formułe patriotyzmu, wolnego od nacjonalizmu, szowinizmu, rasizmu, ksenofobii, ufundowanego na idei demokratycznej i jasności krytycznego widzenia spraw społecznych. Może by odczytać na nowo reakcje pisarki na wezwania Kuczyńskiego, by uciekła $z$ okupowanej Polski: „Ponęta wydostania się gdziekolwiek z nadchodzącego tu piekła zdawałaby się nieodparta. Jednak nie odejdę od mego losu, który jest tu i który jest wspaniały" (20 IV 1944) ${ }^{10}$.

Stosunek Nałkowskiej do wzorca romantycznego można by też odtworzyć, zajrzawszy do jej eseju z 1916 roku Obrona słów. Glossy do „Kordiana”. A także przeczytać komentarze pisarki do wydarzeń politycznych w toku pierwszej wojny światowej i przez całe Dwudziestolecie, a i po wojnie. Łatwo dzisiaj szydzić z pomyłek pisarki, nie mając pojęcia o wszechwładzy kłamstwa i cenzury w reżimie totalitarnym. Czy może wtedy została wciagnięta w takie „uczestnictwo”, o jakie chodzi Dąbrowskiej?

Następna praca w książce, Leny Magnone „Codzienny modernizm”. O diarystyce Zofii Nałkowskiej i Anaïs Nin, też ufundowana jest na pobieżnej tylko znajomości tekstów pisarki. Na wstępie muszę sprostować: ni e ze stawiała m Dzienników Nałkowskiej z Dziennikiem Gombrowicza. Wskazałam tylko na wspólnotę ich antropologii zawartej w utworach, sformułowanej zresztą przez Nałkowską wcześniej. Porównanie dziennika poufnego i utworu w formie dziennika publikowanego w całości za życia autora uważam za nieuprawnione.

Należałoby też ostrożniej wypowiadać opinię o podobieństwie diarystyki Nałkowskiej i Anaïs Nin:

Kształt dziennika Nałkowskiej oraz wi elokrotne przekraczanie granic genologicznych między diariuszem a powieścią (powieścią a diariuszem) zbliża ją bowiem, w dużo większym stopniu niż do autora Ferdydurke, do współczesnej jej pisarki i diarystki, Anaïs Nin. [246; podkreśl. H. K.]

Nie odpowiada to rzeczywistemu sposobowi wykorzystywania fragmentów lub materiału z dziennika (jak np. w Choucas) przez Nałkowską. Rzadko kiedy wprowadza je ona do utworu in extenso, jeżeli - to w postaci cytatów jedno- czy parozdaniowych. Większe partie tekstu dziennikowego ulegają wyraźnej obróbce. W Leysing-Feydey zanotowała: „wszystko, co pragnie nie zniknąć, powinnam zwyczajnie zapisać w dzienniku, z którego później tak doskonale można to zużytkować” (13 III $1925)^{11}$. Sa to więc notatki $z$ „obserwacji uczestniczącej”, materiał rzeczywistości, 
przetworzony w Choucas, Ścianach świata, Kobiecie cmentarnej, sekwencji „szosy”, czyli relacji z wrześniowej ucieczki w Węzłach życia. W innych jej dziełach nie da się wyodrębnić tekstu dziennikowego tak, by można to było nazwać „przekraczaniem granic genologicznych".

Zbieżności biograficzne między diarystkami, zasięg wzoru Marii Baszkircew, skłonność do dandyzmu i „podobny model osobowości” to są już istotne, często dyskusyjne kwestie. Ale czy pojawiają się w tym szkicu?

Autorka zajmuje się właściwie tylko sposobem „gospodarowania” dziennikami przez obie diarystki. Tymczasem pensjonarka Zofia nie miała przekonania, że jej „dzienniki też kiedyś będą [...] wydane oraz że są one dziełami literackimi” (247). Trzeba czytać uważniej. Ona wyobraża sobie wtedy, iż te zwierzenia będą czytane po jej śmierci i sa przeciwieństwem literatury. Jeszcze nie wie, że zostanie pisarka, choć takie predyspozycje w sobie rozpoznaje.

Nietrafiona analogia to również zdanie: „Obie [...] zobaczyły swoje dzienniki w druku" (247). Nałkowska włączyła niewielki fragment notatek z procesu Brzozowskiego do artykułu o tej sprawie w 1936 roku, a następnie jeszcze mniejsze „szczątki” swego diariusza do tekstu publicystycznego Życie i papier w 1953 roku. $\mathrm{W}$ tym drugim przypadku wage miało ujawnienie prywatności tych fragmentów, ubezpieczone słowami: „d a w n e go dziennika” (248; podkreśl. H. K.). Czy można to uznać za „zobaczenie dzienników w druku”? W zestawieniu z Nin, która opublikowała za życia 6 tomów swojej diarystyki? Mnóstwo tu jeszcze nieścisłości i błędów wynikających z nieuważnej lektury Noty wydawniczej do ostatniego tomu Dzienników.

Magnone stwierdza też: „Planuje [...] przepisanie na maszynie całości [...]. Zdążyła sporządzić kopię jedynie tomu pierwszego" (249). Nie jest mi znany taki maszynopis, zwłaszcza „tomu pierwszego”. Podziału na tomy dokonałam ja jako edytorka (nie „edytorzy”, jak autorka dalej pisze). W tomie 1 zamieszczono w Aneksie jedyną wersję zredagowana przez Nałkowską w rękopisie, nie wiemy kiedy, części notatek od 17 VI 1900 do 30 V 1902.

Nietrafionych analogii z Nin, o refrenie „tak, jak Nałkowska”, jest zbyt wiele, by je tutaj komentować. Sytuacja kulturowa, ustrojowa, polityczna obu pisarek była tak odmienna, że te zestawienia wciąż się prują. Spośród licznych błędów rzeczowych autorki sprostować jednak trzeba, choćby dla przykładu, ten, który wynika z tezy Magnone, że Nałkowska jakoby nie dotyka w dzienniku najważniejszych swoich przeżyć. Autorka pisze: „Symptomatyczne, że jedynym zniszczonym przez samą Nałkowska tomem [zeszytem!] dziennika był ten, w którym opisała śmierć matki” (254). Ależ nie! Matka zmarła rok wcześniej, a opis jej odchodzenia jest jak przejmujący, zupełnie jedyny tren na śmierć rodzicielki. W spalonym i niebezpiecznym zeszycie - bo było w nim „wszystko o tych ludziach zza muru” (4 II 1944) ${ }^{12}$, czyli o powstaniu w getcie - był też nieustający lament żałoby po mamie. Nasuwa się wątpliwość, czy Magnone w ogóle przeczytała w całości Dzienniki, jeśli tak często rozmija się $\mathrm{z}$ ich treścią.

Nie ma również dostatecznej analogii między przerabianiem dziennika na fikcję, 
czy raczej podawaniem go za fikcję przez Nin, a spożytkowaniem dziennika w utworach Nałkowskiej. Tu znów Magnone dopuszcza się różnych nieścisłości, łącznie z błędem rzeczowym: debiut Nałkowskiej, Lodowe pola, drukowany był w „Prawdzie” w 1904 roku, nie w 1903. Redaktor, redaktor!

Sumując: uporczywe i naciagane upodabnianie nie tyle diarystyki Nałkowskiej i Nin, co sposobów „gospodarowania” dziennikiem, zarówno w sensie tekstów materialnych, jak też „spiżarni literackiej” do żywienia utworów, należy uznać za wątpliwe. Trudno doprawdy porównywać sytuację życiową i praktykę diarystyczną obu pisarek oraz „zabiegi, jakim oba dzienniki zostały poddane przez osoby trzecie” (258). Nikt nie wydawał części dziennika Nałkowskiej jako powieści (jak w przypadku Nin), moje zaś starania edytorskie nie szły „w kierunku upowieściowienia jej tekstu" (259), wyrażałam natomiast opinię, że diarystyczna proza pisarki układa się w mimowolną powieść.

Lena Magnone z pewnością zna lepiej dzieje diarystyki Nin i prace zachodnich krytyków o twórcach modernistycznych niż Dzienniki i twórczość Nałkowskiej. W zakończeniu szkicu zestawienie $z$ Nin okazuje się właściwie jałowe, skoro owocuje takim, dziwnie nieprzejrzystym, podsumowaniem:

Zestawienie [...] każe się jeszcze raz zastanowić, czy rzeczywiście znajdujemy u Nałkowskiej performatywność podmiotu, postmodernistyczny radykalny konstruktywizm spod znaku Foucaulta i Butler, wyprzedzający praktyki autora Transatlantyku. Zebrany [...] materiał wskazywałby raczej, że ten etap rozwoju diarystyki jest stricte modernistyczny, a tym, co istnieje tu tylko w momencie wykonywania i musi być powtarzane, by zaistnieć ${ }^{13}$, jest nie podmiotowość, ale intymność. [262]

Może owocniejsze byłoby porównanie modeli kobiecości, jakie obie diarystki wpisały w swoje zwierzenia lub jaki dałoby się odtworzyć z doświadczeń ich życia, przebiegającego $\mathrm{w}$ tak odmiennych historycznie i społecznie warunkach. $\mathrm{W}$ tomie programowo feministycznym lepiej by się to tłumaczyło, wymagałoby jednak czytania ze zrozumieniem tekstów oryginalnych, a nie tylko opracowań.

Naruszając kolejność prac w książce, ominę chwilowo dwie następne, żeby odnieść się do szkicu Magdaleny Marszałek (autorki cennej książki o Dziennikach) Granice świadectwa $w$ prozie Zofii Nałkowskiej. (Kilka uwag o „Medalionach”). Jej rozważania, bez wątpienia trafne i przenikliwe, zaczynają się od problemu omawiania Medalionów w szkole, gdzie nauczyciel, „przerabiając” Przy torze kolejowym, każe uczniom zadać sobie pytanie: „czy będąc tam na miejscu strzeliłbym do tej pani [...]”, i najwyraźniej nie rozumie, o czym właściwie pisarka opowiada. Marszałek chce zatem uświadomić nauczającym, że mowa tu o „trudnych, wstydliwych i niewygodnych historycznych doświadczeniach Polaków”, a ten właśnie „medalion” nasuwa też pytanie, „,o to znaczy być świadkiem i dawać świadectwo” (314).

Badaczka nawiązuje do rozwijającej się od lat osiemdziesiątych XX wieku dyskusji na temat świadectwa, świadka i obserwatora zagłady Żydów, odwołując się do terminów Geoffreya Hartmana, autora pracy Shoah and Intellectual Witness (1998): swiadek intelektualny, obserwator (spectator) i naoczny swiadek (bystander).

13 Tu autorka powołuje się na artykuł E. Domańskiej Zwrot perfomatywny we współczesnej humanistyce (,Teksty Drugie” 2007, nr 5, s. 49). 
Świadek intelektualny to ten, który wysłuchuje, z uwagą i dystansem pó źn ego słuchacza, późnych relacji ofiar. Historyczni „naoczni świadkowie” to, jak brutalnie rzecz konkretyzuje Marszałek, „biedni Polacy”:

jak wiemy, przyglądanie się prześladowaniom i mordowaniu Żydów stanowi is totę polskiego doświadczenia okupacyjnego. [317; podkreśl. H. K.]

Taka formuła źle robi pewnej niezbitej prawdzie tego zdania, bo ją wykrzywia. Niesie sugestię, że Polacy nie podlegali ludobójczym praktykom i terrorowi okupanta. Oni też bezsilnie „przyglądali się” egzekucjom, łapankom, wieszaniu zakładników, wywózkom do obozów i innym represjom „po stronie aryjskiej”. Świadomość wyjątkowości Zagłady i antysemityzmu Polaków nie może skutkować amputacją ich wojennej martyrologii.

Autorka Medalionów ,jest idealnym - i do tego wczesnym - świadkiem intelektualnym”, stwierdza Marszałek, „świadomą swojej misji świadczenia pisarką, a jednocześnie kimś, kto intensywnie zmaga się z polskim doświadczeniem bycia "bystanderem"” (318), czego dowodzą notatki w jej wojennym dzienniku.

Przypominając esej Henryka Grynberga z 2002 roku, w którym modyfikuje on motto Medalionów na, jego zdaniem, prawdziwsze: „Ludzie Żydom zgotowali ten los”, i polemikę z nim Marka Zaleskiego, Marszałek wpisuje „pooświęcimski humanizm” (określenie Zaleskiego) Nałkowskiej w „powojenny europejski dyskurs antyfaszystowski”. Europie dał on możność rozliczenia się $\mathbf{z}$ wojną, potępienia rasizmu i nazistowskich zbrodni, ale też „ukształtował politykę pamięci w bloku wschodnim (w tym również w Polsce) i służył jako legitymizacja socjalizmu [...]” (315). Co więcej, sprzyjał polonizacji ofiar Holocaustu, „polegającej na wliczaniu cierpienia i śmierci Żydów do polskiej martyrologii wojennej” (316). To właśnie zjawisko naświetlił Grynberg.

Tu znów brak pewnej precyzji wywodu rodzi wrażenie, że włączenie Medalionów do „paradygmatu antyfaszystowskiego” wiąże świadectwo Nałkowskiej ze wszystkimi wyliczonymi zjawiskami. Marszałek wprawdzie zastrzega się dalej, że nie można obciążać pisarki skutkami szkolnej interpretacji, zgodnej $z$ „obowiązującym wówczas paradygmatem antyfaszystowskim” i $z$, komunistyczno-nacjonalistycznym dyskursem polskiej pamięci historycznej” (316). Zgoda, ale czy dziś ten „paradygmat" nie obowiązuje? Czy już faszyzm pochwalamy? Czy nacjonalizm obsługiwał wyłącznie komunistyczną władzę?

Szkoda, że Marszałek nie przyjrzała się bliżej perypetiom Medalionów przed publikacją i po niej. Książka czekała rok na wydanie i dziś już wiemy, dzięki badaniom Kamili Budrowskiej i jej zespołu z Uniwersytetu w Białymstoku (Zatrzymane przez cezurę. Inedita z połowy wieku XX, 2013), że wstrzymywała druk cenzura, recenzja wewnętrzna była druzgoczaca i odradzała wydanie książki. Nałkowskiej nie przyznano nagrody „Odrodzenia”, mimo wielu pochwał krytyków. W jury zasiadała Maria Dąbrowska (Marszałek przytacza jej pogardliwą opinię o jednym z opowiadań czytanym publicznie przez Nałkowska), która w swoim dzienniku wyrażała oburzenie na Żydów, że się „wpychają” ze swoją martyrologią, a to szybko stawiając pomnik Bohaterom Getta, a to domagając się od niej wspomnienia o zamordowanych współbraciach $z$ Kalisza.

Atakowano z prawa i z lewa. Wymowa książki była dolegliwa dla obu stron, bo 
płynęła z niej uniwersalna - tak! tak! - prawda o zbrodniczych skutkach ideologii nienawiści i przemocy. Partyjna krytyka, w osobie strażniczki marksistowskich dogmatów, Melanii Kierczyńskiej, domagała się innej niż Grynberg modyfikacji motta: „Faszyzm ludziom zgotował ten los”. Postawę ludzi w „,medalionie” Przy torze kolejowym nazywano „zarażeniem faszyzmem”. Ciekawe, że nikt nie wspomina o współczynniku paraliżującego strachu: jawna pomoc Żydom skutkowała przecież śmiercią.

Marszałek podkreśla, że „uniwersalizacja "ofiar faszyzmu" w powojennej recepcji Medalionów „nie tylko prowadziła do marginalizacji ludobójstwa Żydów, ale sprzyjała również jego przemilczaniu i zapominaniu" (316). Grynberg wysłowił prawdę o tym, że ofiary Zagłady zabijano jako Żydów, nie jako polskich obywateli. Powojenne pogromy, afera $z$ hasłem o obozach w encyklopedii PWN-u, Marzec 1968, a dziś zatwardziałość w kłamstwie o narodowej niewinności przy jednoczesnych antysemickich napisach na ścianach domów, wrzaskach kiboli, plugawych tekstach Michalkiewicza, wspomagającego „posługę” ojca Rydzyka i żądaniach czołówki do filmu Ida, nawet oddania Oscara, odnawiają latami ten „doroczny wstyd", który przed wojna piętnowała ta sama Dąbrowska. Otwarcie Muzeum Historii Żydów Polskich „Polin” wciela z powrotem żydowską „obcość” do historii Polski i ukazuje dowodnie, jak wielkiej trzeba odwagi i jednocześnie niesłychanej precyzji i delikatności - $z$ obu stron - przy rozplątywaniu tego odwiecznego węzła.

Autorka ma we mnie sojuszniczkę, gdy zwraca uwagę na dziwny koncept podwójnego narratora opowiadania Przy torze kolejowym. Ten bowiem, od którego pochodzi opowieść, był naocznym świadkiem, biernym jak inni, i on jednocześnie zadaje fundamentalne pytania moralne tej relacji. A przecież: „Gdy znalazł ją, była sama" (cyt. 320).

Marszałek próbuje wykryć antecedencje poetyki Medalionów w Choucas, gdzie istotnie po raz pierwszy Nałkowska wprowadza narratora-świadka. Jednak jego funkcja jest tu całkowicie odmienna niż w Medalionach. Inna książka Nałkowskiej zbliża się bardziej do nich, zarówno formą gatunkową, jak tematyką: ofiar i oprawców, zbrodni i przemocy. To tom opowiadań więziennych Ściany świata (1931).

Uwidocznione tu zastrzeżenia nie zmieniają faktu, że tekst Magdaleny Marszałek należy do paru wartościowych pozycji omawianego tomu.

Nie da się tego powiedzieć o końcowej pracy, artykule Anny Kondrackiej-Zielińskiej o zaczepnym tytule, którego pytanie nie znajduje odpowiedzi w tekście: Komu jest potrzebna dzisiaj Natkowska? Twórczość pisarki $w$ nowej podstawie programowej języka polskiego szkoły ponadgimnazjalnej. Dowiadujemy się z niego, że w „nowej podstawie programowej” proza Nałkowskiej nie jest już obowiązkowa, stanowi materiał do wyboru spośród innych autorów polskich XIX i XX wieku. Przewidziano możliwość sięgnięcia po dzienniki pisarzy, toteż znajdujemy tu propozycje zadań dla uczniów lub tematów maturalnych opartych na lekturze wojennego dziennika Nałkowskiej.

Już wstępna charakterystyka tego materiału budzi niepokój, czy Kondracka-Zielińska jest dostatecznie przygotowana do jego analizy. A cóż dopiero mówić o uczniach? Czytamy:

Nałkowska w zapiskach $\mathrm{z}$ wojny oszczędziła czytelnikom ekshibicjonizmu, nie ma w nich też relacji pisanej z pozycji osoby będącej w centrum wydarzeń historycznych. Jest za to autocenzura, tak 
ja kby autorka bała się, że dziennik dostanie się w ręce Niemców i przez to narazi niewinne osoby. [328; podkreśl. H. K.]

Czy np. tułaczka pod bombami we wrześniu 1939 nie jest „byciem w centrum wydarzeń historycznych"?

Każde zdanie Kondrackiej-Zielińskiej jest tu w taki czy inny sposób niewłaściwe i nietrafne, jak np.:

Wartością wspomnianego tomu Dzienników jest brak [?] tej grozy wojennej, którą uczniowie poznają przy omawianiu choćby opowiadań Tadeusza Borowskiego, Innego świata Gustawa Herlinga-Grudzińskiego czy Zdażyć przed Panem Bogiem Hanny Krall [...]. [328]

Autorka, która, jak się zdaje, jest polonistką w szkole średniej, odczuwa brak materiałów ćwiczeniowych, „standaryzowanych [...], przygotowanych profesjonalnie zestawów" (329). Sama wybiera z wojennego dziennika pisarki tematy egzystencjalne: „Śmierć osoby bliskiej i smutek po jej stracie” (329), „temat starości”, „obserwacja starzenia się osób bliskich” (331), „Co zostaje po człowieku? Co zapamiętuje człowiek, doświadczając historii?" (333) i temat czwarty do rozszyfrowania przez ucznia. Dzieli się on na trzy różne kwestie: refleksje nad własnym strachem przed śmiercią, relacje uciekinierów o straszliwościach Powstania, odpowiedzialność „dalekich ludzi” za śmierć miasta i mieszkańców (tu Kondracka-Zielińska przytacza cytat z dziennika Nałkowskiej pod data 7 VIII 1944).

Każdy fragment opatruje autorka wskazówkami metodycznymi, a w nich również poleceniem, by odnieść się do innych utworów na dany temat. Pytanie, czy wybrano fragmenty właściwe. Ten o śmierci osoby bliskiej np. jest wysoce nietrafiony, można znaleźć stosowniejsze. Zalecony kontekst literacki jest niewspółmierny do lapidarnego „pigułkowego” stylu diarystki i zbyt szeroki. Nie wiemy, czy uczeń ma te utwory w spisie lektur, czy też nauczyciel powinien je wymienić albo omówić na lekcji. Jakkolwiek jest, kilka słów Nałkowskiej o tych, co zdecydowali o wybuchu powstania, nie uzasadnia wskazania na „inne teksty krytyczne wobec Polski i Polaków” (334), czyli Ferdydurke, Transatlantyk i Dziennik Gombrowicza oraz Grób Agamemnona Słowackiego, ze względu na zbyt daleko idące uogólnienia i niewspółmierność gatunkową powieści, poematu i dziennika poufnego. Streszczenie angielskie u końca artykułu mówi, że wybór fragmentów z Dzienników czasu wojny zapoznaje uczniów z innym obrazem Nałkowskiej, specyfika jej pisania. Wątpię mocno, skoro schematyczne wskazówki metodyczne autorki artykułu rozmijaja się z rzeczywistą zawartością fragmentów i nie zachęcają do pozytywnej odpowiedzi na pytanie w tytule.

Wskazane dotychczas błędy i słabości tomu, nierówny jego poziom i budzące sprzeciw założenia ideologiczne kulminują pod koniec skandalem. Sa nim dwa teksty, w których dominująca w tomie tendencja lustracyjna przybiera postać prymitywnej i niegodziwej insynuacji. Dwie autorki podjęł się dowieść, że Nałkowska była antysemitką! Ta absurdalna teza, sprzeczna $z$ całą biografią i twórczością pisarki, została najwyraźniej zasuflowana przez redaktorkę książki jako zwieńczenie rocznicowych wysiłków grona polonistek-feministek. Spytana przeze mnie o wymowę tytułu i wstępu, o te „ograniczenia” Nałkowskiej, odparła: „Choćby jej antysemityzm!” Huknęła więc na zakończenie mało odkrywczego „projektu” petardą internetowego „hejterstwa”. 
Zapowiedź takiej intencji znalazła się na początku tomu, w omawianym już szkicu Klaudii Ziewiec, gdy rozważa ona przypadek Marusi Orychowej, centralnej postaci Węży i róż, i wtrąca:

Jej zwyczajność wzmocniona została obszernym i bardzo interesującym (ze względu na liczne antysemickie wtręty spotykane we wczesnej twórczości Nałkowskiej) opisem urody Żydówek z rodziny Oliwnych [...]. [33-34; podkreśl. H. K.]

Bez dowodów.

Pierwsza prezentacje takich „dowodów” przedstawiła Marta Tomczok (Cuber), która zgodnie z tytułem „Krew i dymy holokaustów”. „Węże i róże” wobec kwestii żydowskiej $w$ twórczości Zofii Natkowskiej tropi ten wątek w powieści z 1915 roku oraz w dzienniku pisarki. Formuła tytułowa zapowiada metodę: analizowanie utworu literackiego jako wypowiedzi ideologicznej, tożsamej z publicystyka.

Nie wiedzieć czemu Tomczok nazywa Nałkowską „portrecistką polskich Żydów” (266), ,admiratorką tematu żydowskiego, pieczołowicie opracowanego w cyklu krótkich opowiadań" (czyli w Medalionach) (267). Dodaje zaraz, że funkcjonujący zwłaszcza w obiegu szkolnym i akademickim obraz pisarki jako filosemitki nie jest obrazem jedynym:

Pomija się w nim zarówno złożoną sylwetkę twórczą autorki Rówieśnic, jak i wiele tekstów, w których temat żydowski w ogóle się nie pojawia albo pojawia się na zupełnie innych zasadach niż w Dziennikach czasu wojny lub Medalionach. [267]

Tomczok obwinia więc na wstępie pisarkę, że nie poświęciła całej twórczości „portretowaniu Żydów”.

Dalej podprowadza nas do nie nazwanego jeszcze oskarżenia osobliwą interpretacja genealogii duchowej Nałkowskiej, „inteligentki polskiej, dzięki ojcu dobrze znającej myślenie socjalistycznej i liberalnej inteligencji drugiej połowy wieku XIX" (267). Trzeba by dodać, że także początków XX wieku, jeśli pamiętać o datach urodzin Zofii i Wacława. Temu obozowi ideowemu Tomczok przypisuje negatywne stereotypy dotyczące Żydów. Toteż wyznanie Nałkowskiej, z niedokończonej książki o ojcu, o jego wpływie na jej „sposób widzenia świata i ludzi” i uwewnętrznienie zasady, że „ludzie wszystkich narodów i wyznań są sobie równi”, kwituje pogardliwie jako „naiwnie prostoduszne” (267-268).

A to dlatego, że ojciec Zofii wpisał do jej „dziewczyńskiego pamiętnika” maksymę: „wartość ewolucyjna jednostki mierzy się siłą i rodzajem nienawiści i zdolnością wprowadzania jej w czyn" (cyt. 268; nb. nie ma tego w zachowanym rękopisie Dzienników). Te „zbójeckie nauki”, jak je Tomczok nazywa, nie zadając pytania, czego kazał nienawidzić Nałkowski, miały sprawić, że „pewna część [...] poglądów [jego córki] na kwestię żydowską znalazła się tam [tj. w powieści Węże i róże] dzięki uważnej lekturze pism ojca” (268). Zaszczepił jej nienawiść do Żydów?

Analiza, jakiej Tomczok poddaje rozważania Nałkowskiego w jego artykule Bezstronny głos $w$ sprawie żydowskiej (1903) z ksiażki Jednostka i ogót (1904), zdradza słaba znajomość epoki i zagadnienia. Składa się z garstki chaotycznych zdan, z których wciąż przebija potrzeba autorki, by dowieść „niechęci, z jaką Nałkowski odnosi się do Żydów". Tomczok szuka jej zwłaszcza w polemicznym stylu uczonego, zdradza ja jego „mentorsko-siłowy ton”: 
[...] Nałkowski dzięki swym atakującym metaforom próbuje wykorzystać sytuację uciśnionego społeczeństwa żydowskiego i jego wielowiekową niewolę uczynić probierzem rozwoju i oświecenia. [270]

Jest to zbitka słów domagających się wyjaśnienia. Zwłaszcza że Tomczok przeciwstawia uczonemu (,Odpowiada mu Hilary Nussbaum”) cytat z 1881 roku, z epoki pozytywizmu, z zupełnie innej sytuacji historycznej: propozycję żydowskiego intelektualisty, oferującego, w imię „naszego przywiązania do kraju”, „usługi we wszystkich gałęziach państwowej służby i na każdem polu pracy” (270), co też wymagałoby przecież odpowiedzialnej wykładni. Tomczok w przypisie tłumaczy tę „imaginowaną wymianę poglądów” chęcią pokazania, że „po obu stronach barykady [!] nie brakowało ochotników do rozmów [...]”. Należałoby może odnieść się raczej do broszury Bernarda Lauera, przyjaciela Nałkowskiego, Nasze rachunki i syonizm. Głos na czasie przez Belaryusza (1903), która uczony w swym szkicu omawia, bo to byłoby bardziej zasadne.

Chociaż autorka trzyma w dłoni magiczną różdżkę niezawodnie wykrywającą antysemityzm, to z jej bezładnych wywodów nie dowiemy się w końcu, czy Nałkowski i cała „socjalistyczna i liberalna inteligencja polska drugiej połowy wieku XIX”, która bazowała na trzech stereotypach: „ekonomicznym, asymilacyjnym i "gatunkowym “" (267), co jakoby przejęła w spuściźnie córka uczonego, to antysemici, czy nie?

Polem operacyjnym różdżki ma być powieść Węże i róże, którą Tomczok, najwyraźniej słabo rozeznana w literaturze modernistycznej, przedstawia jako płód pod każdym względem poroniony:

W powieści tej, jak w ogniskowej, skupia się wizerunek Nałkowskiej, jakiej nie znamy i znać raczej nie chcemy: nieumiejącej zapanować nad formą powieści i powstrzymać się od dość chaotycznego cytowania lektur; zafascynowanej egzotyką żydowskiego świata w sposób bliski - niespotykanemu u niej - homoerotyzmowi [no, no], a mimo to przemawiającej męskim [?], stronniczym głosem, przybierającej pozę etnografki, która porusza się pośród Żydów niczym wśród obcego jej ludu i opisuje go jak osobny gatunek, różniący się zarówno od tego, kto o nim pisze, jak i od tych, którzy o nim czytają, tak bardzo, że o asymilacji w tym wypadku nie ma już mowy. [267]

Obok różdżki bowiem Tomczok ma i zaklęcie magiczne: asymilacja.

A teraz przewód sądowy, równie poplątany, jak prezentacja poglądów Nałkowskiego. Tomczok przypomina oświadczenie pisarki przed drukiem powieści w 1913 roku w „Sfinksie”, odcinające się od ówczesnych „dzikich igrzysk antysemickich” (4 I 1913; cyt. 270), czym „tłumaczyła czytelnikom swój ob o jęt ny s to s u nek d o s prawy i wynikającą stąd autoteliczność [...] powieści [...]” (270-271; podkreśl. H. K.). Jak się ma do tego sąsiadujące orzeczenie, że autorce Węży i róż „bliskie były poglądy prożydowskiej lewicy”? Tomczok więc pyta, dlaczego napisała „tak bardzo niezaangażowaną powieść i czy rzeczywiście Wężom i różom brakuje potencjału ideologicznego" (271).

Zatem badaczka wydłubuje $z$ wielowątkowej powieści „niejasny znaczeniowo zestaw obrazów, dzięki którym narracja wyraża treści nieujawniane w ogólnie dostępnych kanałach komunikacyjnych [...]" (271), i buduje z nich własny utwór konstrukt ideologiczny, mający dowieść, że Węże i róże to powieść jednego tematu, żydowskiego. Według niej to „powieść o Raissie Benoni”, którą dzięki pozorom powieści „autotelicznej i parnasyjskiej” (raczej: parnasistowskiej) „można izolować 
od irytujących autorkę konfliktów społecznych” (271; podkreśl. H. K.), ale naprawdę Nałkowska

włącza ją do debaty na temat konsekwencji asymilacji Żydów na ziemiach polskich, pokazując fiasko tego projektu w historii pięknej i bogatej żydowskiej intelektualistki, która przegrała ze swoją rodziną walkę o niezawisłość i oświecenie. [271]

Ta brawurowa ,jazda po bandzie” wynika pewnie z przekonania autorki, że nikt takiej staroci sprzed stulecia nie czyta, można więc fantazjować, ile dusza zapragnie. Zwłaszcza jeśli Tomczok najwyraźniej nie ma dostatecznych kompetencji do analizy tekstu z początku XX wieku na tle kultury epoki. Jeśli obdziera się wątek Oliwnych - jeden $z$ paru doniosłych tematów powieści - z parnasistowskiego właśnie kostiumu, ignorując zamysł artystyczny pisarki, i odcina się go od pewnych stałych motywów jej wczesnych książek, to tworzy się mistyfikację, rezultat ideologicznej manipulacji, a nie interpretacji.

Tomczok właśnie nie rozpoznaje powtarzających się idei i wątków twórczości młodej Nałkowskiej. Rodzina żydowskich finansistów i panujący w niej kult pieniądza przedstawia obcy pisarce świat wartości, obcy społecznie, nie etnicznie. Czy Oliwni są zasymilowani? Czy c $\mathrm{h}$ c a się asymilować? W powieści funkcjonują w tych samych kreggach towarzyskich co reszta postaci, łączą ich $\mathrm{z}$ nimi nawet serdeczne więzi, jak np. Marusię z panią Oliwną, której powierza ona swoje udręki. Jednocześnie $z$ dystansem i oporem istnieje w powieści fascynacja kulturową odmiennością, egzotyzmem estetycznym tych ludzi, zwłaszcza Raissy. Ona ucieleśnia - poza wiekami dziejów ludu Izraela - także kreowany przez młodą Nałkowską model kobiecości: pięknej i mądrej. Klęska Raissy to nie żadne fiasko asymilacji - czy ona do niej dazży? - to kolejny dramat „nieprzystosowanych” bohaterek Nałkowskiej, rwących się do swobody i samorealizacji. Drugim, siostrzanym dramatem kobiecości jest tragiczny los głównej bohaterki Węży i róż, Marusi.

Prezentację tej książki jako powieści o Żydach rozłamuje Tomczok przeglądem Dzienników pisarki, poszukując w nich narysowanej przez siebie twarzy Nałkowskiej-antysemitki. Popada przy tym w śmieszne chwilami anachronizmy, gdy z perspektywy Zagłady ogląda każdą wzmiankę i każdy obraz Żyda w zapiskach diarystki. Antysemickie wydaje jej się zarówno słowo „Żyd”, jak i jego brak (wtedy dopowiada!). Rządzi nia jakby lękowe tabu, naiwne pojmowanie poprawności politycznej, a nie wiedza o epoce. Tak bardzo chce udowodnić swoją tezę, że manipuluje tekstem, rozmijając się $\mathrm{z}$ jego wymową.

Oto cztery fragmenty z dziennika pisarki (cyt. 274), z których Tomczok lepi kukłę Nałkowskiej-antysemitki. Cytat pierwszy:

Dziś miałam zabawną rozmowę z Żydem pewnym, utrzymującym w Wołominie telefon ku użytkowi publicznemu. Okazało się, że ten miły pan w chałacie czytał Majmonidesa i Spinozę. Mina, z jaka wyrażał się lekceważąco o Szolem Alejchemie, Szalomie Aszu i - Belmoncie, inteligencja, zamknięta ściśle w ramę prawowierności, dowcip i przebiegła rezerwa. [9 IV 1913]

Druga notatka mówi o spotkaniu z żołnierzami Legionów u pisarza Gustawa Daniłowskiego, wyjątkowej sposobności poznania i posłuchania bojowników o wytęsknioną niepodległość, samotnych straceńców, jak śpiewali o sobie w hymnie I Brygady. 
Więc i Kaden [Bandrowski], po cywilnemu zresztą, rad sobie i dosyć towarzysko miły (tym razem z żoną, ładną, trochę tłustą Żydówką). Młody żandarm polowy, malarz prócz tego, z niewinnym figlarnym cynizmem mówił, jak zdarza mu się wieszać Żydów (jednych za szpiegostwo, innych dla przykładu) i że to nie robi wrażenia, taka silna jest w człowieku ta rasowa nienawiść. Kiedy już wiszą, wówczas rysuje ich w swym szkicowniku. [16 I 1916]

Następna jest wzmianka: „wybrałam się z Wandą Sztekkerową na sztukę Słonimskiego (zajmującą i dowcipna) [...]" (2 I 1929). Ostatni zaś fragment dotyczy bulwersującej środowisko literackie sprawy zaręczyn młodego krytyka, Alfreda Łaszowskiego, członka faszyzującego ONR-u, z córką Leśmiana. Partia zabroniła mu jednak ślubu $z$ „nieczystą rasowo” kobietą. Wówczas Łaszowski zaproponował narzeczonej związek bez ślubu. Poeta, dowiedziawszy się o tym, wpadł w furię, spoliczkował Łaszowskiego i wyrzucił go z domu. Mówiono, że incydent ten przyczynił się do śmierci Leśmiana.

Wczoraj jeszcze raz mimo wszystko Łaszowski [...] i jego narzeczona, śliczna, malutka córka Leśmiana, która w tym wszystkim nie przestaje przecież być (podobno tylko w połowie) Żydówką. [27 IX 1937]

Tę paradę cytatów poprzedzaja jeszcze dwa fragmenty z Dzienników, mające wyjaśnić, czemu w pierwszym zdaniu Wę̇̇y i róż Nałkowska przedstawia rozmawiające panie tak: Żydówka i Marusia. Według Tomczok anonimowość pierwszej (dodajmy: chwilowa) oznacza „osobny gatunek, oddzielną klase, egzotyczny szczep”. Tomczok sądzi, że narodowości żydowskiej nie wolno ujawniać? Czy nie jest to nieświadome myślenie antysemickie właśnie, jak wiele innych uwag tej autorki? Pani Oliwna, „Żydówka”, prezentuje się w tej pierwszej scenie ujmująco, jako osoba mądra, współczująca i taktowna. Krytyczny dystans pisarki do niej daje znać o sobie dopiero wtedy, gdy chlubi się ona kolekcją strojów, bogactwem.

Tomczok podpiera swój sąd dwoma innymi wyimkami z Dzienników, by dowieść jeszcze, że zdradzają one niskie pobudki niechęci Nałkowskiej do Żydów. Latem 1935 przebywała ona w Nowym Saczu. Na spacerze w parku nad brzegiem Dunajca spotkała dwie tamtejsze Żydówki, bardzo starą i drugą młodszą, która ją zagadnęła. W opisie obu kobiet powtarza się szczegół: brylantowe kolczyki. U starej kobiety zadziwił Nałkowską sposób chronienia cennej ozdoby: „każdy kolczyk uwiązany był zwykła czerwona bawełna na barku”. O drugiej wspomniała: „I ta miała brylanty w uszach", przy tym jednak zapisała jej opowieść o przeszłości miasta i zniszczeniach, jakie pięknemu parkowi miejskiemu przyniosła powódź z poprzedniego roku: „Nie tylko krowy, dachy, deski płynęły wodą, ale - tu zniżyła głos - nawet fortepiany..." (21 VII 1935) ${ }^{14}$.

Tomczok zaś skwapliwie nas uświadamia, że „brylanty okazały się dla pisarki ważniejsze od fortepianów" (i tu przyciska pedał), podczas gdy Żydówka opisała ,jedną z tragiczniejszych nowosądeckich powodzi, pochłaniającej [!] wszystko, co znajdowało się wokół, wraz z pięknymi salonowymi instrumentami [...]" (272).

Wzmacnia efekt, cofając się do lata 1913, kiedy Nałkowska żali się w dzienniku, że znajome panie, odnajmujące na lato parter „domu nad łąkami”, z nudów wycią- 
gają ją na rozmowę i zabierają drogocenny czas na pisanie książki (tychże Wężów i róż).

Patrzę na nie ze zdumieniem, jak niechętnie czytają, jak wiecznie mówią, jak nigdy nie umieją sobie wystarczyć. Roznosi je tak sadło, próżniactwo i nie zarobione pieniądze. [23 VII 1913; cyt. 272-273]

Idąc śladem wtrącenia: „między nimi Belmontowa”, Tomczok śmiało stwierdza, że notka „dotyczy innych Żydówek” (272), jakby Belmontowa mogła mieć tylko takie towarzystwo. Jak zazwyczaj - autorka opuszcza coś istotnego: „Pomimo ich rozlicznych zalet prywatnych i życzliwości niekłamanej, pienię się w duszy od złości i smutku" (23 VII 1913; cyt. 272). Dodajmy, że Belmontowie byli bliskimi przyjaciółmi rodziny Nałkowskich. Dlaczego jednak wady tych pań, dosadnie tu wytknięte, miałyby definiować narodowość, a nie charakter i pozycję społeczną? Tomczok wie: „są one Żydówkami [...] (o czym Nałkowska szczególnie pamięta)” (273). Dowodów w tekście brak.

Wszystkie te preparaty mają zdefiniować „cechy światopoglądu Nałkowskiej”.

Pierwszą z nich jest stereotypowa wizja żydowskich kobiet [...]. Oceniając Żydówki, pisarka bierze pod uwagę aspekt biologiczny (czy są młode i ładne) oraz ekonomiczny (czy są dobrze ubrane). Cechę drugą stanowi stereotypowe widzenie Żydów jako grupy społecznej, której autorka Choucas [?] przypisuje staroświeckość, konserwatyzm, zacofanie, przebiegłość oraz chytrość. Po trzecie, [...] brakuje komentarza, w którym Nałkowska odpierałaby społecznie niestosowne lub niesprawiedliwe oceny żydowskich obywateli. Mowa tu nie tylko o skandalicznej wypowiedzi żandarma polowego, ale również o sztuce Antoniego Słonimskiego Murzyn warszawski, traktowanej przez samego autora jako narzędzie walki $z$ „ciemnotą ortodoksji żydowskiej”. [274]

Ta miałka wyliczanka, żenujący popis uproszczonego - by nie rzec: prostackiego - ujęcia zagadnienia, ma to do siebie, że kłóci się z wymową tekstu. Tomczok dorzuca jeszcze do tego bukietu ostów hodowli własnej ciężki zarzut, że Nałkowska nie potępiła komedii Słonimskiego, „najwyraźniej godząc się z poglądami autora, które w końcu nie odbiegały tak dalece od poglądów nieszczęsnego [?] żandarma polowego" (275). Autorka nie ma hamulców. Zatem zasymilowany Żyd Słonimski odczuwał też „tak silną rasową nienawiść” do współplemieńców, że aż dziw, że ich nie wieszał, tylko wykpiwał. Skądinąd w Alfabecie wspomnień odnosi się do tej sztuki i Tomczok to wie, bo stąd wzięła określenie „ciemnota ortodoksji żydowskiej”, ale przemilcza.

Wracając do Nałkowskiej, to nikt przytomny w pełnym szacunku i sympatii migawkowym portrecie czytelnika Spinozy nie dopatrzy się ani antysemityzmu, ani stereotypu. Cytat o żandarmie Tomczok skróciła o niewygodne dla niej zdanie, które jest właśnie tym jakoby brakującym komentarzem:

W duszy raz po raz odzywa się dziwny sentyment, że oto - po tylu latach - widzi się przecież swoich wojowników, a potem dreszcz odrazy, że są przecież tacy ostatecznie, jak inni. [16 I 1916] ${ }^{15}$

Jeszcze dobitniej wyraziła swoje obawy o przyszłość odradzającej się ojczyzny: „Inną jest znów sprawą, że owa Polska będzie narodowo-demokratyczna [czyli endecka] i antysemicka” (7 IX 1914) ${ }^{16}$. 
Prostowanie fałszerstw i aktów ignorancji autorki jest zadaniem wyczerpującym. Nawet dawny pałac książęcy w środku miasta staje się u niej „dworkiem ziemiańskim, niegdyś myśliwskim” (273; mowa o obecnej siedzibie Oliwnych w Wężach i różach). Fałszerska biegłość idzie u niej w parze $\mathrm{z}$ obojętnością na literacką konwencję epoki. Wyniosły grymas, z jakim podsumowała Węże i róże (co zacytowałam na początku) jako wyrób Nałkowskiej, ,jakiej nie znamy i znać [...] nie chcemy”, dobitnie o tym świadczy, łącznie $z$ rzekomym „homoerotyzmem”.

Tomczok swój zamysł ideologiczny wciska na siłę w teksty Nałkowskiej. Interesuje ją to tylko, czego w powieści nie ma, a według niej być powinno. Zakłada, że Węże i róże powinny stać się traktatem o kwestii żydowskiej, a więc pyta:

Dlaczego o Polakach i Żydach narrator (autorka) mówi(a) różnymi głosami? Z jakich powodów narrator rezygnuje $z$ uczciwej opozycji jednych wobec drugich? Dlaczego Nałkowska nie przedstawia żadnej dyskusji Polaków i Żydów, poprzez przesunięcie bohaterów żydowskich na dalszy plan tworząc pole nierównej walki i dziwnej gry? [282]

Można odpowiedzieć tylko, że Nałkowska napisała p o w i e ś ć, a nie tekst dyskursywny, i napisała ją o czym innym. Skoro jednak nie wypełniła dyspozycji wydanych przez Tomczok po 100 latach, to „postać Żydówki przestaje być nośnikiem istotnych treści ideowych” (283). Ciekawe, jakich, bo zarzut należy do repertuaru nakazowej teorii socrealizmu, a tymczasem „istotnych treści ideowych”, które sama Raissa wypowiada, jest w tej postaci aż nadto, tylko trzeba rozumieć, co się czyta.

Tomczok „szuka haków” na pisarkę w Dziennikach, ale selektywnie. Nie zwróciła uwagi na jej notatki z podróży do Włoch z Florą Epstein i jej rodziną, może ich po prostu nie zrozumiała? Nałkowska, chwilowa dame de compagnie, trochę gość, trochę protegowana, źle się czuła wśród tych bogaczy. Napomknęła w dzienniku o swej obcości duchowej w owym gronie.

Tęsknię do wydobycia się spod ustawicznego nacisku cudzego świata pojęć. Chęć widzenia człowieka, dla którego te same słowa odpowiadałyby tym samym wartościom. W danym razie jest wręcz przeciwnie. [16 IV 1910] ${ }^{17}$

Dziwna jest w tym konsekwencja, w związaniu koniecznym bogactwa z nędzą psychiczną. Właściwie mogłoby tak nie być. [4 V 1910] ${ }^{18}$

Kontakt z tym środowiskiem dostarczył Nałkowskiej tła i figur do wątku żydowskich finansistów. Jej dystans do nich wynika w sposób oczywisty z konfliktu wartości, a nie $z$ rasizmu. Można by powiedzieć, że „rasa” właśnie jest dla niej źródłem rozkoszy estetycznej i służy do parnasistowskiej eksploracji starożytnej kultury. Irzykowski nazwał to snobizmem rasy.

Tomczok znajduje inny klucz: marksistowska ortodoksje (jak wiemy, w praktyce współżyjącą bez przeszkód $\mathrm{z}$ antysemityzmem). „Antysemityzm” Nałkowskiej ma mieć źródła... klasowe! Podrozdziałowi swych wywodów nadała badaczka tytuł: Postszlachcianka patrzy na Żydów, będący „subtelną” parafrazą tytułu słynnego artykułu Jana Błońskiego. Oto jej wynalazek: dziadkowie Nałkowskiej utracili nie- 
gdyś posiadłości ziemskie, a ona „szczególnie pamięta”, że znajome Żydówki „należą do narodu, który przejął (wykupił, wynajął, wydzierżawił) wiele szlacheckich majątków”, więc siła rzeczy „wobec nowobogackich Żydów, gospodarujących posiadłościami poszlacheckimi bez szacunku dla tradycji, Nałkowska pozostaje bezlitosna i nieprzejednana" (273; podkreśl. H. K.).

Próżno szukać w powieści potwierdzenia tych afektowanych przymiotników. To tylko emanacja umysłu Marty Tomczok.

Powinna ona jednak lepiej wniknąć w genealogię rodziny Nałkowskich. Ojciec Wacława szydził ze swoich ziemiańskich paranteli, stracił nędzną resztkę majątku z własnej winy, jego osierocony syn znalazł się w skrajnej nędzy i nie miał najmniejszych sentymentów do szlacheckiej tradycji. Był za to nieprzejednanym właśnie krytykiem posiadaczy, bynajmniej nie żydowskich. Zofia, córka dwojga ubogich miejskich inteligentów, miała za tradycję szlachectwo wiedzy i talentu. Nigdy się na inne nie powoływała.

Fałszerska inwencja autorki rodzi ciąg pomówień bez dowodu:

Większość zapisków diarystki ma w sobie coś z klasizmu [modny termin, analogia do seksizmu i ageizmu, dyskryminacja z powodu przynależności klasowej, potworek językowy], czyli światopoglądu, w którym spotykają się dystans szlachcianki wobec obcej jej kultury Żydów i niechęć ekonomiczna, wynikająca z niesprawiedliwego - zdaniem Nałkowskiej - awansu niektórych żydowskich obywateli. [273]

Tomczok mnoży takie wymysły bez opamiętania: „w postszlachciance, jaką była Nałkowska, odezwały się liczne uprzedzenia i stereotypy, tak charakterystyczne dla jej przodków [„,resortowe dzieci”?]”, „te nieżyczliwe lub mało empatyczne kategorie oceny stosowała Nałkowska w swoich pismach w zasadzie do wybuchu II wojny światowej”. B e z d o w o d u. Dalej: „opisuje w sposób ogólnikowy i "rasowy “ Żydów w dziennikach" (278). B e z dow odu.

Korekty wymagają tak samo rozmaite uwagi o Wężach i różach: Nałkowska bierze odwet na Żydach za poniżenia towarzyskie - jakie?; bogate Żydówki mszczą się na biedniejszych Polkach - gdzie, jak?; Orych patrzy na Żydówki oczyma Weiningera (ale ten - sam Żyd - pisał tak o kobietach an sich, doktor mówi raczej językiem rzeczywistego lekarza, Walentego Miklaszewskiego, polemisty Nałkowskiej po jej odczycie na Zjeździe Kobiet); Ernestyna ulega fascynacji estetycznej i homoerotycznej Raissa (to drugie to raczej trybut na rzecz modernistycznych idei o związkach sztuki z „chucią, a może „odważna” pożyczka z powieści Rachilde); Ernestyna jakoby przedstawia swoją rzymską modelke ,jako rzeczywiste uosobienie matki (żony) i prostytutki” - nic podobnego! I jeszcze raz konkluzja: Nałkowska to „kasztelanka ze złotym warkoczem".

narracja o ich [tj. Żydów] „najeździe” na Polskę i zawłaszczeniu szlacheckich dóbr [...] ma charakter rewanżu poszkodowanej [?] na ludziach, którzy mają więcej, niż mieć powinni. Należą do nich zarówno Belmontowa, jak i nowosądeckie Żydówki, córka Leśmiana [?!], a przede wszystkim Flora Epstein. [281-282]

Zastanawia znajomość antysemickich stereotypów. Czyja mentalność znalazła tu wyraz - Nałkowskiej czy jej pogromczyni? Kłamliwe tezy o tym, co jest antysemickiego w Dziennikach, idą w parze z równie nieprawdziwym wyliczaniem, czego 
nie ma, np. refleksji o narastającym w latach trzydziestych antysemityzmie. Ależ są! Tomczok wytyka pisarce, że gdy wspomina o żydowskich przyjaciołach, jak Belmont, Korczak, Schulz, „nie pojawiają się [...] uwagi o [ich] tożsamości [...]”.

Nie ma ich również wtedy, gdy Belmont czy Schulz giną, a przecież to właśnie wtedy, w roku 1941 czy w 1943, Nałkowska bez podejrzeń o uprzedzenia mogłaby napisać o tych ludziach „Żydzi”. [275; podkreśl. H. K.]

Naprawdę wtedy mogła? „W Dziennikach 1939-1944 nikt jej nie zmus za do porzucenia definicji (i nazwy) narodu żydowskiego, a mimo to pisarka unika słowa "Żydzi" [...]" (276; podkreśl. H. K.). Tomczok tylko w przypisie dopuszcza cudzą sugestię, że może to była wojenna ko ni eczność. Czy miała im od razu zakładać opaskę z gwiazdą Dawida?

Ignorancja Tomczok jest równie wielka jak jej impet lustracyjny. Nawet w tytule zawarła niesmaczną aluzję cytatem z powieści: „krew i dymy holokaustów”, sugerującą insynuacje artykułu. Nałkowska zaś wykorzystała pojęcie holokaustu nie „w ramach zdobnictwa stylistycznego”, tylko jako elementu Tradycji - biblijnej ofiary całopalnej ze zwierzat, zwykle dla przebłagania Jahwe za swoje winy. Roman Zimand daremnie kiedyś protestował przeciw niestosownemu użyciu słowa „holocaust" jako nazwy Zagłady narodu.

Cały wywód Tomczok opiera się tyleż na niekompetencji, co na bezzasadnym przeświadczeniu, że wie, jak na le ży pisać o żydowskich współobywatelach. Jej wskazówki, zazwyczaj negatywne, są nad wyraz mętne i anachroniczne, a sprowadzają się do nakazu asymilacji i zakazu ujawniania odrębności etnicznej i „obcości” Żydów. Czy troskliwa autorka słyszała o idei syjonistycznej, jak również o dążności środowisk ortodoksyjnych do uchronienia tożsamości narodowej, religii i języka w „obcym” chrześcijańskim otoczeniu? Głębsza wiedza o zagadnieniu może by pohamowała w niej pewność agresywnego ideologa, który używa nieetycznych sposobów do przeprowadzenia swoich oszczerczych zamysłów. Literatura i artystyczne środki wyrazu to domena raczej jej obca.

Wywody i metody Marty Tomczok odnajdziemy w tekście amerykańskiej autorki, Rachel F. Brenner, Zofia Nałkowska: Milczenie i Stowo $w$ relacji świadka Holokaustu (w przekładzie Anny Kondrackiej-Zielińskiej). Nic o autorce nie wiemy poza informacja w przypisie, że ofiarowała nieodpłatnie do tego tomu rozdział o Nałkowskiej ze swej książki The Ethics of Witnessing. The Holocaust in Polish Writers' Diaries from Warsaw 1939-1945 (Evanston 2014).

Na wstępie Brenner względnie poprawnie przedstawia sylwetkę pisarki (nie bez błędów rzeczowych), ale gdy przystępuje do odtwarzania jej postawy wobec Zagłady, stajemy się świadkami przykrego nieporozumienia. Autorka myli dziennik intymny $z$ wypowiedzią dyskursywną - artykułem, esejem, traktatem, czasem też z utworem. Nie czuje i nie rozumie lapidarnego, aluzyjnego języka Nałkowskiej i reguł kapryśnego, nieciagłego zapisu dziennikowego. A najważniejsze - nie ma chyba dostatecznej wiedzy o warunkach życia w okupowanej Warszawie. Mimo nieporównywalnej skali zbrodni na Żydach, po aryjskiej stronie także działały okrutne prawa okupanta, przemoc i śmierć. One też każdy gest pomocy Żydom czyniły śmiercionośnym. Zagrożeniem życia była już sama próba dokumentacji czy komentarza zbrodni dokonywanej na żydowskich mieszkańcach Warszawy. To 
dlatego przecież Nałkowska rzuciła w ogień ten zeszyt dziennika, w którym było „wszystko o tych ludziach zza muru”, gdy w jej kamienicy gestapo dokonywało rewizji u sassiada.

Ta niewiedza sprawia, że Brenner „rozlicza” Nałkowską z obowiązku opisania Zagłady - w dzienniku! - i nieustannie konstatuje jej niewydolność w tym względzie. Niby dostrzega oczywistą niemoc słowa wobec niewyobrażalnego zła, wręcz niewyrażalność ogromu zbrodni i cierpienia, a równocześnie osądza pisarkę za niedostatek woli i chęci dawania świadectwa martyrologii Żydów. Nie zastanawia się jednak nad sposobami i możliwościami zdobywania wiedzy o tym przez Nałkowską. Mówi wręcz o jej milczeniu, „które wymógł na niej ciężar traumy dnia codziennego” (288; pewnie miało być: powszedniego). Nie wiemy właściwie, co chciała w tej okropnej stylistyce wyrazić.

Orzeka następnie, że w przeciwieństwie do Iwaszkiewicza i Wyleżyńskiej, też autorów dzienników okupacyjnych, którym udało się „uniknąć efektu emocjonalnego kalectwa i upośledzenia przez traumę" (289), Nałkowskiej się to nie udało. Nie wiadomo, co się w tych drastycznych epitetach kryje. Towarzyszą temu pomyłki rzeczowe, które podważają wiarygodność i sensowność tekstu.

Brenner przywołuje notatkę $z$ dziennika datowaną 4 lutego 1944. Wtedy stempel na książce z czytelni uświadomił pisarce, że tom ten pochodzi z zamordowanego już getta, i sprowadził wizję unicestwionego życia dzielnicy, a także jeszcze jeden paroksyzm żalu za spalonym zeszytem dziennika. Brenner raz pisze, że Nałkowska te notatki „czuła się w obowiązku zniszczyć” (289), a dalej, że „miała potrzebę zniszczyć” (290). Wnioskując $z$ dat, Brenner zakłada, iż „znajduje się tam również opis deportacji do Treblinki, podczas których zlikwidowano 300 tysięcy Żydów" (289-290). Nie wiadomo przecież, jaka była wiedza Nałkowskiej i co zapisała. Brenner ma jej za złe, że nie odtworzyła utraconych notatek, wini ją za „stałą niezdolność do powtórnego wyobrażenia sobie nie tylko wydarzeń $z$ getta, ale także innych wypadków [...]" (290).

Wzmianka o książce-symbolu skłania znów Brenner do dziwnej i niezrozumiałej opinii:

skojarzenia Nałkowskiej pomiędzy życiem getta a normalnymi intelektualnymi czynnościami i społecznymi interakcjami ujawniają daremność działań diarystki, która wyobrażała sobie ograniczenie własnych doświadczeń we współodczuwaniu, a co próbowała zrealizować, po mijając milczeniem temat ludobójstwa w getcie. [...] Nałkowska zadeklarowała swą niezdolność do tego, aby zrozumieć zagładę getta. [290-291; podkreśl. H. K.]

Rozważania Brenner cechuje jakaś dwudzielność: każdą partię jako tako trafnej refleksji nieodmiennie kończy ona błędem, szokująco mylną diagnozą i refreniczną sentencją oskarżenia. Przykład:

Fakt, że strach przed gestapo zmusił ją do zniszczenia zapisków, wywołuje ogromne cierpienia Nałkowskiej, spowodowane przez wrażenie, że artystycznie i moralnie zdradziła sama s i e bi e. Ponieważ nigdy się nie dowiemy, jak pisarka była szczegółowa i dokładna w zapiskach odnoszących się do deportacji, wydaje się oczywiste, że musiała być albo niechętna, albo niezdoln a do podzielenia się swymi w s po mni enia mi. Najdalej w swym utrwaleniu grozy deportacji idzie Nałkowska przy opisie śmierci Janusza Korczaka. [292; podkreśl. H. K.]

Nie ma w Dziennikach takiego opisu, bo być nie mogło! W rękopisie jest tylko 
litera K. Kontekst pozwolił na domniemanie, że chodzi o Korczaka w następującym zdaniu: „I K[orczak?] inny jest teraz niż w chwili, gdy dowiedziałam się, że nie żyje. $Z$ jego śmiercią od mego ogromnego życia odłamał się cały blok przeszłości" (26 I 1943) ${ }^{19}$. Możemy tylko przypuszczać, że wiadomość o jego śmierci zanotowała pisarka w spalonym zeszycie. A dalej czytamy absurdalny wniosek Brenner:

Milczenie Nałkowskiej na temat śmierci Korczaka mówi wiele o jej oporze, być może niechęci przed uwiecznieniem żydowskiej walki. [292; podkreśl. H. K.]

Jak wiemy, Korczak wyszedł z dziećmi i personelem Domu Sierot na Umschlagplatz 5 lub 6 sierpnia 1942, a data jego śmierci w Treblince czy w drodze do niej nie jest znana. Nie ma też związku $z$ „walką”, czyli powstaniem w getcie.

Brenner cytuje przejmujące słowa grozy i rozpaczy polskiej pisarki w obliczu tragedii płonącego, mordowanego getta:

Jak mogę być do tego zmuszona, żeby w tym być, żeby już tylko żyjąc - przystawać! Jest to jeszcze hańbą, nie tylko męczarnią. Jest to straszny wstyd, nie tylko współczucie. Wszelkie wysiłki, by wytrzymać, by nie dostać obłędu, by jakoś zachować siebie w tej grozie, uczuwa się jak winę. [29 IV 1943; cyt. 293]

Cytuje, ale dokonuje egzegezy tego lamentu $\mathrm{z}$ lotnością słonia, używając wyrazów, których ciężaru chyba nie rozumie:

Poczucie ws półudziału wywołało w niej poczucie winy za to, że ocalała. Stało się tak prawdopodobnie dlatego, że jej i roniczna [?] reakcja wobec spalonego dziennika została wywołana pragnieniem przeżycia fizycznego zagrożenia. W tym samym czasie samooskarżanie pisarki, że bycie świadkiem równa się przyzwoleniu na tragedię, ujawniło, że jej świadomość stara się pomniejszyć efekt terroru, ludobójstwo. Przekonania Nałkowskiej doprowadziły ją do samooskarżeń o tchórzliwą zmowę z oprawcami. [293; podkreśl. H. K.]

Takie odczytanie intencji pisarki nabiera, niestety, charakteru gorszącej bredni.

Obsesyjność zarzutów Brenner kłóci się z partiami rzeczowej informacji, np. o tym, że „zapiski o ludności żydowskiej [...] [były] szczególnie zakazane i surowo karane przez Niemców", co tłumaczy konspiracyjny język Nałkowskiej, gdy mówi o męczeństwie Żydów. Tuż po tym Brenner wraca do swego: świadczy to jedynie o „niezdolności do zmierzenia się na piśmie $z$ likwidacją getta”. Co więcej, wylicza autorka, Nałkowska nie wspomina też w dzienniku o szmalcownikach, o „żydowskich uciekinierach szukających schronienia”, o „grupach wychudzonych więźniów pracujących po aryjskiej stronie" (293).

Nawet gdy pisze o małym żydowskim chłopcu dzwoniącym do drzwi po prośbie, to dla Brenner „adnotacja nie jest zbyt dokładna” i ma to być jakoby „wspomnienie na temat getta” (293), choć Nałkowska utrwaliła tu znany każdemu warszawiakowi tamtego czasu obraz żebrzących żydowskich dzieci, małych „przemytników” z getta, żywiących niekiedy całe rodziny. Można jedynie zacytować Nałkowską: „Bez słów wiadomo, o co chodzi, wiadomo wszystko" (14 I 1942) ${ }^{20}$. A czy Brenner wia- 
domo, że mąż siostry pisarki był z pochodzenia Żydem i wyskoczył z okna w dalekim Lyonie, by nie wpaść w ręce francuskich żandarmów „łowiących” Żydów na rozkaz niemieckiego okupanta?

Nie koniec na tym. Brenner rozszerza listę zaniechań Nałkowskiej jeszcze o przemilczenie „osławionej karuzeli na placu Krasińskich”, bo pisarka nie była „zdolna do przelania na papier [...] przerażających szczegółów wydarzeń, których była świadkiem”. Ale - uwaga! - „Takiej powściagliwości nie odnajdziemy jednak w pamiętnikarskiej [!] woli utrwalania opresji doznawanych przez Polaków" (294). Na dowód Brenner cytuje parozdaniową migawkę uliczną z 12 V 1944: przejazd „bud” z więźniami i oprawcami, wiozących ich na publiczną egzekucję i poddaje ten urywek „wyolbrzymiającej” egzegezie, chcąc dowieść, że Nałkowska potrafiła znaleźć środki literackie, by przedstawić cierpienia Polaków i swoją identyfikację z nimi, „w kontraście do utrwalonych w prozie [?] Nałkowskiej obrazów Żydów [...]” (295). Brenner trzykrotnie w różnych słowach ponawia ten sam wniosek:

Pisarka odczuwała wspólnotę $\mathrm{z}$ doświadczeniami więźniów, co pozwoliło jej [?] być świadkiem brutalnych aktów przemocy wobec jej znajomych [?] Polaków, ale zarazem nie mogła odnaleźć w sobie wcześniejszej empatii, by zrozumieć, a następnie w sposób logiczny i spójny opisać likwidacje getta. [295-296; podkreśl. H. K.]

Poraża nas totalna bezradność wobec tych słów i wobec głuchoty Brenner na wymowę urywkowych notatek Nałkowskiej. Skape, rwane, lecz przejmujące słowa pisarki patrzącej od grobu matki na płonace za murem cmentarza getto skłania Brenner jedynie do wniosku, że wobec tragedii Żydów zawiodła Nałkowską sprawność pisarska. Badaczka stwierdza, że „opowieść się rozpada”, ogłasza:

Rosnąca niespójność tego zapisu [...] ukazuje [...] porażkę Nałkowskiej w zakresie wytworzenia znaczącego zapisu przywołanych wydarzeń w czasie rzeczywistym. Paraliżujący niepokój i groza tych wydarzeń nie tylko okaleczyły jej zdolności komunikacyjne, ale także uniemożliwiły empatyczne połączenie z perspektywą odbioru, co mogłoby uczynić los mieszkańców getta w pewnym stopniu bardziej zrozumiałym. [297]

Gdybyż przytoczone zdania były w ogóle zrozumiałe! Autorka ukazuje, cytując innych, głęboką więź Nałkowskiej z ludźmi jako cechę główną jej osobowości i pisarstwa. Robi to jednak po to, by tym dobitniej podkreślić, że wobec Żydów zabrakło jej empatii, stąd niemoc jej talentu i humanizmu w obliczu ich tragedii. Tu jeszcze raz za argument służy scenka $z$ „budą, w której Brenner wyróżnia szeroki wachlarz „spójnych” środków literackich (a dla Żydów Nałkowska ich nie miała!).

Brenner nie umie czytać dziennika, nie odbiera całej gamy emocji, grozy, bólu, empatii właśnie: „I myśleć o tym. I żyć”, „Nie mogę wytrzymać myśli, zmieniam się od nich" (28 IV 1943; cyt. 296) i inne. Nie potrafi rozwinąć skrótowych notatek diarystki, wciąż myląc dziennik intymny z publicystyką, kroniką historyczną czy utworem literackim.

Pisząc o Medalionach, Brenner dokonuje niedopuszczalnej etycznie manipulacji. Utożsamia antysemickie wypowiedzi „kobiety cmentarnej” z postawą Nałkowskiej. „Nawet jeśli pisarka stara się zaświadczyć o Zagładzie Żydów, jej a n ty s emickie racjonalizacje "przełamuja tekst" [...]" (303; podkreśl. H. K.). 
Amerykańska autorka skądinąd wypowiada się o Medalionach z uznaniem. Przywołuje zachwyt Iwaszkiewicza, krytycznie komentuje znaną notatkę z dziennika Dąbrowskiej: „bardzo słabe - i makabra z czasów okupacji”, „nudzi i razi”. Rozważa obszernie, ale bez przekonania, wyznanie Nałkowskiej: „Sam temat [...] sprawił, że użyłam tych realistycznych środków wyrazu” (cyt. 301), stwierdza bowiem: „Jednakże tematyka Medalionów przeciwstawia się realistycznemu sposobowi pisania" (301). Nie ujawnia wszakże, jaka poetyka byłaby tutaj stosowna. Nie rozumie, że dla Nałkowskiej rozstrzygająca była wartość dokumentarna tych relacji, ich prawda, bo działy się w realnym bycie, a nie w przestrzeni mitu.

Trudno śledzić sensowność wywodów Brenner, bo gubi się ona stale w niejasnych i sprzecznych ze sobą orzeczeniach. Ma się wrażenie, że trafne i pozytywne sady o Nałkowskiej powtarza za literatura przedmiotu, a sama ciagle powraca do obsesyjnej podejrzliwości oraz zarzucania jej złych intencji. Siebie zaś nie podejrzewa wcale o uprzedzenia i rozmijanie się $z$ wymową tekstów pisarki.

Nie pojmuje też wartości jej decyzji, aby oddać głos ofiarom, zamienić autora w bezwzględnie lojalnego skrybę ich opowieści. Czyta tekst w sposób naiwnie dosłowny, wciąż domagając się deklaracji autorskich. Ma więc za złe pisarce, że w opowiadaniu Wiza „nie ujawnia współczucia dla "brudnych, owrzodzonych, ostrupiałych, [...] chorych, a nawet umierajacych" kobiet [...]” (308). Jakby unaoczniony obraz tych kobiet nie wystarczał.

Przy takim poziomie rozumienia utworu nie dziwi ostateczna ocena Medalionów jako owocu „reedukacji” ich autorki, ukazujacego jej „osobistą i pisarską przemianę”. Z całego tekstu wynika, że „przemieniła się” i wyedukowała $\mathrm{z}$ antysemityzmu, braku empatii i współczucia dla Żydów, z „kalectwa emocjonalnego” oraz niewydolności twórczej. Trudno o bardziej fałszywą diagnozę. Idzie za tym dziwnie mętna konstatacja końcowa:

Groza ludobójstwa, skonfrontowana z niezdolnością autorki do dawania świadectwa, ujawnia potrzebę ponownego sprawdzenia możliwości ludzkich przekonań. [311]

Potykamy się nieustannie o takie ułomności tekstu, o przykrą niedołężność językową, zawinione z pewnością w dużej mierze przez okropny przekład. Tłumaczka potrafi zmienić zaplombowany wa gon pociąu z setką kobiet wiezionych do obozu w „medalionie” Dno w s a m o c h ó d, zmienia też ciągle płeć opowiadajacych kobiet na "główny bohater”, by nagle, w tym samym zdaniu, dodać mu również "główną bohaterkę". Jak można było dopuścić do druku materiał tak kaleki w treści i formie, nie tknięty okiem ani ręka redaktora!

W sumie więc toporne wysiłki Marty Tomczok i Rachel F. Brenner, by wmówić Nałkowskiej antysemityzm wbrew powszechnej wiedzy o jej osobie i poglądach, robia ponure wrażenie. Prymat politycznej tezy i zabiegi z repertuaru propagandy: manipulacje, fałszerstwa, insynuacje, zdominowały kompetencje i etykę badacza literatury. Tonacja niektórych innych, „lustracyjnych” tekstów tego tomu spokrewnia je też, niestety, $z$,hejterstwem” internetowym.

Autorka programowych manifestów feminizmu za młodu, a w późniejszych utworach portrecistka kobiecości narażonej na różnoraką opresję w świecie patriarchatu, sama jako postać będąca obrazem zarówno niedoli kobiet, jak i triumfu ich walecznej woli i talentu, jest poddana w tej książce degradującej „lustracji”. 
Rzeczywiste treści feministyczne i genderowe jej twórczości pozostały tu w istocie nierozpoznane.

Odpowiedzialność za brzydkie „rewelacje” tego zbioru dzieli jej redaktorka z recenzentką, Ingą Iwasiów, profesorką Uniwersytetu Szczecińskiego, wykładowczynią Gender Studies i ceniona pisarką. W recenzji wydawniczej przemilczała ona, iż tom zawiera prace pomawiające Nałkowską o antysemityzm. Może włączono je później i gdyby je znała, zawahałaby się przed ich firmowaniem? Wolę tak sądzić. Zachwala natomiast wydawcy ten zbiór jako potencjalny podręcznik akademicki. Strach pomyśleć, iż rzesze studentów miałyby odpisywać z tej książki jej nienawistne hipotezy i niezliczone błędy rzeczowe.

Przykro powiedzieć, ale część winy za treści i rażące braki redakcyjne omówionej tu publikacji spada na wydawcę, czyli kierownictwo Feminoteki, które przekazało tom do druku praktycznie bez redagowania (choć podano nazwiska redaktorki i nawet konsultantki tekstów angielskich!). Nie za bardzo książka przysłużyła się sprawie kobiet. Podobnie jak te jej autorki, które wykazały daleko idące „ograniczenia” (we wstępie) wiedzy i „czujności” feministycznej, odgrzewając stare koncepty i stereotypy androcentrycznych krytyków. A niektóre przekroczyły „granice” przyzwoitości.

\author{
Abstract \\ HANNA KIRCHNER Warsaw
}

HATER POLISH STUDIES ON THE BOOK "GRANICE NALKOWSKIEJ" (“NAŁKOWSKA'S BORDERS")

The article is a polemics by an outstanding expert in Nałkowska's work and editor of her Dzienniki (Diaries) with a collective volume devoted to the writer which aspires to feminist criticism. Majority of the volume's contributors trace the ideological "limitations" of the great writer, an icon of Polish feminism, unfortunately reaching for disgraced rules of socialist realism and pop-cultural patterns, especially the Internet hate speech, thus resorting to manipulation and libel at variance with Nałkowska's work. Extreme examples of it are two sketches falsely imputing Nałkowska's anti-Semitism. The volume, devoid of editorial proofreading, contains numerous mistakes and errors, including content matter ones. 